\title{
A Counterfactual Obama Presidency: Policy PROGRESS WITH LESS DAMAGE TO THE DEMOCRATIC PARTY
}

\author{
JOHN D. GRAHAM* \\ ALYSSA JULIAN $^{* *}$
}

\section{INTRODUCTION}

During the presidential elections of 2008 and 2012, Barack Obama helped the Democratic Party. He generated enthusiasm with the Democratic base, harvested support from independent voters, and attracted new voters such as young people and African Americans. ${ }^{1}$ The energy from Obama's campaign helped the Democratic Party record a net gain of twenty-three House seats and eight Senate seats in 2008 and an additional eight House seats and one Senate seat in $2012{ }^{2}$ Democratic gains were also made in state races for legislature, governor, and other offices. ${ }^{3}$ Thus, the Democratic Party clearly benefited from Obama's

* Since July 2008, John D. Graham has served as dean of the Indiana University School of Public and Environmental Affairs (SPEA). Located in Bloomington and Indianapolis, SPEA is one of the largest public affairs schools in the nation. Before coming to IU, Graham was dean of the Frederick Pardee RAND Graduate School (PRGS) at the RAND Corporation in Santa Monica, California. During the George W. Bush administration, Graham served as Administrator, Office of Information and Regulatory Affairs in the Office of Management and Budget, and from 1990 to 2001, Dean Graham founded and led the Harvard Center for Risk Analysis (HCRA). He earned his PhD in Urban and Public Affairs from Carnegie Mellon University. This Article derives primarily from Dean Graham's book, Obama on the Home Front: Domestic Policy Triumphs and Setbacks (Ind. Univ. Press 2016). This Article is a revised version of the presentation given during the Indiana Law Review Symposium held on November 6, 2015 entitled Partisan Conflict, Political Structure, and Culture.

** Alyssa Julian is a research assistant at the Indiana University School of Public and Environmental Affairs. She worked on the book, Obama on the Home Front: Domestic Policy Triumphs and Setbacks.

1. Inside Obama's Sweeping Victory, Pew Res. CTR. (Nov. 5, 2008), http://www. pewresearch.org/2008/11/05/inside-obamas-sweeping-victory/\#economy-was-dominant-issue [https://perma.cc/HGZ2-EKCR]; see generally Tom Bevan \& Carl M. Cannon, 21 Reasons for Obama's Victory and Romney's Defeat, ReAl CleAR Pol. (Nov. 7, 2012), http://www. realclearpolitics.com/articles/2012/11/07/21_reasons_for_obamas_victory_and_romneys_defeat _116090.html [https://perma.cc/H5J4-6PPF].

2. John Woolley \& Gerhard Peters, Seats in Congress Gained or Lost by the President's Party in Presidential Election Years, Am. Presidency Project (Dec. 19, 2014), http://www. presidency.ucsb.edu/data/presidential_elections_seats.php [https://perma.cc/NML5-9TF9].

3. See State Legislative Elections, 2008, BALlOTPEDIA, https://ballotpedia.org/State legislative_elections,_2008 [https://perma.cc/4YM6-SHUV] (last visited Oct. 30, 2016); State Legislative Election Results, 2012, BALLOTPEDIA, https://ballotpedia.org/State_legislative elections_results,_2012\#tab=Election_analysis [https://perma.cc/8UVM-66KQ] (last visited Oct. 30, 2016); Election Results 2008, N.Y. Times (Dec. 9, 2008), http://elections.nytimes.com/2008/ 
campaigns during his presidential election and re-election bids.

President Obama experienced two midterm elections, in 2010 and 2014, and those two elections saw the Republican Party make huge electoral gains at the expense of the Democratic Party. ${ }^{4}$ Adding the results from the two midterms together, the Democratic Party lost a total of seventy-six House seats and fifteen Senate seats. ${ }^{5}$ Those political massacres were devastating to Obama's legislative agenda (as the Democrats lost their majority in the House in 2010 and their Senate majority in $2014^{6}$ ). The massacres also weakened the Democratic Party at the local, state, and national levels of government.

It is tempting to think that midterm elections will not be influenced by public perceptions of the President since the President's name is not on the ballot. In reality, some midterm elections seem to be a virtual referendum on the performance of the current President, especially in the recent period of polarized American politics.

The sobering truth is that a President's party rarely gains House seats at a midterm election. It has happened only three times in the last century (1934, 1998, and 2002). ${ }^{7}$ The average House losses by the President's party are substantial: roughly thirty seats at the first midterm election and forty seats at the second midterm contest. ${ }^{8}$ In the Senate, the average midterm loss for the President's party is about three seats, which is substantial given that only thirtythree Senate seats are up for grabs at each national election. ${ }^{9}$ These averages conceal huge variability, which suggests that large losses are not inevitable and that specific circumstances matter. In many midterm elections, the President's party manages to minimize its losses of House seats to single digits. ${ }^{10}$ For

results/governor/votes.html [https://perma.cc/ES2C-XS86]; 2012 Election Governor, REALCLEAR PoL., http://www.realclearpolitics.com/elections/live_results/governor/ [https://perma.cc/W373MF65] (last visited Oct. 30, 2016); Democrats Net Two Secretary of State Seats, FivETHIRTYEIGHT (Nov. 10, 2008, 11:30 PM), http://fivethirtyeight.com/features/democrats-net-two-secretary-ofstate/ [https://perma.cc/A9R7-YWXD]; State Executive Official Elections, 2012, BALlOTPEDIA, https://ballotpedia.org/State_executive_official_elections,_2012\#tab=By_office [https://perma.cc/ZQM5-NW85].

4. Woolley \& Peters, supra note 2 (illustrated by seats lost in President's party).

5. $I d$.

6. Jeff Zeleny, G.O.P. Captures House, but Not Senate, N.Y. Times, Nov. 3, 2010, at A1, http://www.nytimes.com/2010/11/03/us/politics/03elect.html?pagewanted=all [https://perma.cc/CF6U-XUXW]; Jonathan Weisman \& Ashley Parker, G.O.P. Takes Senate, N.Y. TiMES, Nov. 5, 2014, at A1, http://www.nytimes.com/2014/11/05/us/politics/midterm-elections. html?mtrref=www.google.com\&assetType=nyt_now [https://perma.cc/BXX8-UWBD].

7. Vincent A. Pacileo IV, The Freedom of the Lame Duck: Presidential Effectiveness in the Post-Twenty-Second Amendment Era 9, http://cspc.nonprofitsoapbox.com/storage/Fellows2011/ Pacileo-_Final_Paper.pdf [https://perma.cc/AM32-SX4A].

8. Id. at 10 .

9. Matthew N. Green, 2010 Midterm Election, in The Obama Presidency: A Preliminary Assessment 129, 130 (Robert P. Watson et al. eds., 2012).

10. Susan Davis, Why Democrats Won't Take Back the House; GOP Has Built-In Advantages 
example, the Democratic Party fared well in 1998 (during Clinton's second term) while the Republican Party won seats in 2002 (during George W. Bush's first term). ${ }^{11}$

Both parties experience midterm electoral setbacks in Congress, but the average losses are larger for the Democratic Party than the Republican Party. Since World War II, the average midterm loss in the House for the Republican Party when the GOP occupies the White House is twenty-one seats; while it is twenty-nine seats for the Democrats. ${ }^{12}$ In the Senate, the average midterm loss is 3.2 seats for Republicans and 5.0 seats for Democrats. ${ }^{13}$

While the Democrats often experience large midterm setbacks, the magnitude of Obama's midterm losses is so large that it begs for explanation. This Article analyzes how Obama's policies influenced the electoral fate of his party brethren in Congress and explores whether Obama could have taken steps to curtail the Democratic Party's midterm losses without compromising his agenda.

Specifically, this Article evaluates President Obama as a party leader. As a successful party leader, a President helps grow his political party in Congress during good times and helps attenuate losses in bad times. He does so through both political activity and policymaking.

"Political activity" is defined here to include a variety of activities: fundraising for the party and particular candidates, delivering speeches that energize the base (nationally or locally), and making personal appearances on behalf of candidates or groups in states and districts throughout the country. Presidential policymaking is often seen as advancing national interests, but it can also help boost the electoral fortunes of the President's party.

"Policymaking," defined as executive actions and legislative proposals, influences partisan outcomes at the polls through a variety of mechanisms. Since the President is the leader of his party, his job-approval rating and general popularity tend to elevate the attractiveness of all candidates on the ballot affiliated with his party. A President's policymaking may boost his popularity if his initiatives are broadly popular. Thus, we have seen some presidents give priority to popular initiatives. ${ }^{14}$ Even if the President's initiatives are controversial, divisive, or even unpopular, effective policymaking on such issues helps fashion an image that the President is an engaged and influential politician. Voters (especially independent voters) respect effective presidents, even if they do not agree with all of their policies. On the other hand, ineffective presidents are likely to become unpopular. If the President's policy priorities are blocked in the Congress (due to their unpopularity, partisan gridlock, or opposition from

in November Elections, USA ToDAY, Aug. 11, 2014, at 1A, http://www.usatoday.com/story/ news/politics/2014/08/10/house-republican-majority-2014/13585905/ [https://perma.cc/Y3XYR6SE].

11. Woolley \& Peters, supra note 2.

12. Id.

13. Id.

14. See Brandice Canes-Wrone, Who Leads Whom?: Presidents, Policy, and the PUBLIC 185-92 (2006) (legislative success and policymaking involving the public). 
powerful interests), the President's job-approval rating will suffer, and indeed there may be collateral damage to the standing of his party.

Overrated is the notion that well-timed presidential policies can help the President's party at a midterm election by creating favorable outcomes for voters. It is not easy for the President and his policy team to schedule favorable policy outcomes-particularly economic ones-with the precision necessary to influence the outcome of a midterm election. It is particularly difficult to target favorable policy outcomes in the one-third of states with a Senate race or to the ninety or so competitive congressional districts that could plausibly flip one way or another. Thus, we assume it is rarely feasible for the President to enact and implement policies with such temporal precision that electoral outcomes will be reliably impacted.

\section{How the President's Policies Become Electorally Sensitive}

The opposing party in Congress recognizes that a policy victory for the President is also a plus for the President's political party, and a loss for the President is a plus for the opposing party. As a result, presidential policy priorities create a dynamic of "strategic opposition," where opposition to a policy initiative intensifies when the President designates the initiative a White House priority. In fact, the opposing party in Congress may oppose a presidential initiative not because they oppose the policy on the merits but because the President proposed it and may gain politically from its passage. ${ }^{15}$

When a President asks members of his party in Congress to vote for controversial or unpopular initiatives, he cross-pressures his partisan allies in ways that create electoral risks for the party. Cross-pressured members may have some cover if the White House succeeds in attracting bipartisan support for a controversial proposal. But, the leaders of the opposing party in Congress will call for unity in opposition to the President's initiative, reducing the opportunities for bipartisan support of a White House initiative. ${ }^{16}$

There is now a significant body of evidence that roll-call votes by members of Congress influence congressional election outcomes. ${ }^{17} \mathrm{~A}$ highly risky vote for

15. See generally David Fontana, Government in Opposition, 119 YALE L.J. 548, 600-07 (2009) (discussing unified and divided government pros and cons and referencing Democrats' reaction to torture memos pre- and post-Democratic majority in 2006); Matthew Hoye \& Jeremy Diamond, Can Obama's Community College Plan Get Through Congress?, CNN (Jan. 10, 2015, 11:24 AM), http://www.cnn.com/2015/01/09/politics/obama-community-college-fate/\# [https:// perma.cc/96XV-EJE9] (describing Republican attendance at President Obama's speeches for community college plan but lack of support for federal program and endorsement of state program).

16. Jonathan Martin, G.O.P. Unites Against Obama, N.Y. Times, Feb. 14, 2016, at A23, http://www.nytimes.com/2016/02/14/us/politics/republicans-unite-against-president-obama.html [https://perma.cc/AC6N-MJRN] (describing Republican candidates and Republican members of Congress united to prevent nomination replacing Scalia).

17. John A. Ferejohn, A Tale of Two Congresses: Social Policy in the Clinton Years, in THE Social Divide Political Parties and the Future of Activist Government 49, 57-80 
a presidential initiative is one that antagonizes influential segments of the member's district or state. Party-line votes in favor of unpopular or divisive presidential initiatives are a danger sign for members of Congress from the President's party, since such votes create an opportunity for the opposing party to nationalize a midterm election by making it a referendum on the incumbent President.

Before analyzing how Obama's policy agenda may have contributed to the midterm defeats, this Article examines why some electoral losses for Democrats in 2010 and 2014 were unrelated to policy and therefore should be seen as inevitable. That requires a look at the structure and dynamics of the two elections.

\section{IMBALANCE IN NUMBER OF SEATS AT RISK}

It is not fair to blame President Obama entirely for the Democratic Party's large 2010 electoral losses because there were some uncontrollable structural factors working against the Democrats. The biggest single factor was the imbalance in the number of seats at risk (sometimes called the party's "exposure"), especially the large number of Democratic House members representing districts that were friendly to a Republican challenger. ${ }^{18}$ In the House, the Democrats were defending 257 seats compared to 178 for the Republicans. ${ }^{19}$ The situation was far more balanced in the Senate, where the Democrats were defending only one more seat (nineteen) than the Republicans (eighteen). ${ }^{20}$

Given the structure of the 2010 election and the partisan imbalance in exposure to its potential losses, it was likely that the Democratic Party would experience significant losses in the House. The structure of the Senate contests was balanced in number, but the Democrats were defending seats in more states that are historically competitive between the two parties. ${ }^{21}$ Thus, the prospects of picking up Senate seats were better for the Republican Party than for the Democratic Party.

\section{THE RISE OF THE TEA PARTY}

A key factor in the 2010 and 2014 midterm elections was the rapid

(Margaret Weir ed., 1998); see generally Brandice Canes-Wrone et al., Out of Step, Out of Office: Electoral Accountability and House Members' Voting, 96 AM. Pol. SCI. REV. 127, 127-40 (2002); see generally Gary C. Jacobson, 1994 House Elections in Perspective, 111 PoL. SCI. Q. 203, 203-23 (1996).

18. Anthony Salvanto \& Mark Gersh, For Republicans, Could 2010 be Like 1994?, CBS News (Sept. 24, 2009, 11:14 AM), http://www.cbsnews.com/news/for-republicans-could-2010-belike-1994/ [https://perma.cc/UEF8-4MYB].

19. Charles Mahtesian, Senate 2010: Most Endangered Seats, PoLiTico (Oct. 9, 2009, 4:06 AM), http://www.politico.com/story/2009/10/senate-2010-most-endangered-seats-028103 [https:// perma.cc/H6WS-Q99E].

20. $I d$.

21. Id. (illustrating specific seat battles across key states). 
development of the Tea Party, the loose coalition of populist conservatives and libertarians who rallied around vice presidential nominee Sarah Palin during the 2008 campaign and were seen by liberals as a reactionary wing of the Republican Party. ${ }^{22}$ Obama's race, life story, and progressive values, coupled with his ambitious legislative agenda in 2009 (TARP renewal and corporate "bailouts,"23 stimulus spending,${ }^{24}$ the Affordable Care Act, ${ }^{25}$ cap and trade, ${ }^{26}$ and liberalization of immigration ${ }^{27}$ ), frightened the Tea Party to such an extent that the grassroots movement spread like brushfire in many regions of the country. A common sentiment among "stop Obama" activists was that the country was headed toward socialism..$^{28}$

Some activists affiliated with the Tea Party saw Obama as a radical Muslim. ${ }^{29}$ A related critique that alarmed evangelical Christians was the idea that Obama was anti-Christian, exemplified by his support for gay rights and abortion. ${ }^{30}$ Tea Party concerns overlapped with broader concerns in the Republican base that Obama was anti-gun, anti-farmer, anti-business, anti-property, anti-freedom, antimilitary, and anti-American. Some observers resorted to ridicule of the Tea Party's simplistic views, but the effects of the ridicule may have been to further energize the Tea Party, which rapidly became effective at organized political activity. ${ }^{31}$

The emergence of the Tea Party made it much more difficult for Republican members of Congress to consider collaborating with President Obama. Many conservative GOP voters did not simply oppose Obama, they despised and feared him. ${ }^{32}$ As Obama sought bipartisan collaboration in Congress to further legitimize

22. Gary C. Jacobson, The Republican Resurgence in 2010, 126 POL. SCI. Q. 27, 31-33 (2011); Vanessa Williamson et al., The Tea Party and the Remaking of Republican Conservatism, 9 PERSP.ON POL. 25, 27 (2011), http://scholar.harvard.edu/files/williamson/files/tea_party_pop.pdf [https://perma.cc/9D54-VXF3].

23. Jacobson, supra note 22, at 42-48.

24. $I d$.

25. $I d$.

26. Mark Drajem \& Lynn Doan, Don't Like Obama's Carbon Plan? Fine, Here's Cap and Trade, Bloomberg (Aug. 4, 2015, 5:00 AM), http://www.bloomberg.com/news/articles/2015-0804/don-t-like-obama-s-clean-power-plan-fine-here-s-cap-and-trade[https://perma.cc/D9PC-UFC4].

27. Michael D. Shear, Obama Moves Ahead on Immigration, N.Y. TIMES, Nov. 21, 2014, at A1, http://www.nytimes.com/2014/11/21/us/obama-immigration-speech.html [https://perma.cc/ 5YYB-HDAU].

28. Jacobson, supra note 22 , at 33.

29. Id. at 33-34.

30. Greg Jaffe, The Quiet Impact of Obama's Christian Faith, WASH. Post (Dec. 22, 2015), http://www.washingtonpost.com/sf/national/2015/12/22/obama-faith/ [https://perma.cc/FAE7R3T2]; Gary C. Jacobson, The Politics of Congressional Elections 226 (8th ed. 2013) (describing questions of Obama's faith and natural born status).

31. See Williamson et al., supra note 22, at 25 (describing structure, organization, and development of Tea Party).

32. George C. Edwards III, Evaluating Opportunities and Strategies in the Obama 
his agenda and legacy, Republicans in Congress sensed political danger and became highly unified in opposition to his policy initiatives, sometimes for completely partisan, strategic reasons.

In the Republican primaries in 2010 , the Tea Party ran its own candidates in numerous elections, often seeking to dislodge incumbent Republicans who were seen as too inclined to compromise with Obama. ${ }^{33}$ Even when Tea Party candidates lost in the 2010 Republican primaries, they sent a strong signal to the Republican winners that collaboration with Obama was unacceptable. Republican candidates for Congress in 2010 urged voters to send President Obama a message by voting against Democratic candidates. ${ }^{34}$

The emergence and growth of the Tea Party was largely out of Obama's control, as in our view it was a reaction to aspects of his political identity (e.g., race and progressive orientation) that he could not adjust. Nonetheless, the content of Obama's policy agenda in 2009-2010 made the Tea Party's task easier than it would have been. This thesis is explored more fully below.

\section{THE ECONOMY AND THE 2010 MiDTERM ELECTION}

It is not easy for a challenger to defeat an incumbent member of Congress. Over the past thirty years, the reelection rates for House incumbents have been between ninety-five and ninety-nine percent; for Senate incumbents they have been between eighty and ninety-five percent. ${ }^{35}$ When incumbents do lose reelection, a poor economy is often a contributing factor. ${ }^{36}$ The immense disruption of the economy caused by the Great Recession (December 2007-June 2009 ) was still working its way through labor markets in the fall of 2010. The $9.6 \%$ unemployment rate in October 2010 was down slightly from a peak of more than ten percent earlier in 2010, but far above the roughly five-percent rate that economists often consider representative of a healthy economy. ${ }^{37}$ Additionally, the millions of jobless Americans who had given up looking for work were not even counted in the official rate of employment. ${ }^{38}$

Presidency, in The Obama Presidency: Appraisals and Prospects 37, 48 (Bert A. Rockman et al. eds., 2012).

33. Williamson et al., supra note 22, at 35-36.

34. JACOBSON, supra note 30, at 226-27 (describing Republicans calling referendum on Obama).

35. Marc J. Hetherington \& William J. Keefe, Parties, Politics, and Public Policy IN AMERICA 50-51 (11th ed. 2007).

36. Kevin B. Grier \& Joseph P. McGarrity, The Effect of Macroeconomic Fluctuations on the Electoral Fortunes of House Incumbents, 41 J. L. \& ECON. 143, 147-48 (1998).

37. Unemployment in October 2010, BuREAU OF LAB. STAT. (Nov. 10, 2010), http://www.bls. gov/opub/ted/2010/ted_20101110.htm [https://perma.cc/E2H4-A3Z3]; Chris Farrell, Why Not Target a 3\% Unemployment Rate?, BloomberG Bus. WK. (May 2, 2013, 5:16 PM), http://www. bloomberg.com/news/articles/2013-05-02/why-not-target-a-3-percent-unemployment-rate [https://perma.cc/S99U-RBGG].

38. See generally Missing Workers: The Missing Part of the Unemployment Story, Econ. 
Public expectations for a speedy recovery were out of proportion to what federal policy makers were able to generate. The agonizingly slow recovery of labor markets was somewhat surprising to macroeconomists: typically, when recessions originate in the financial sector of the economy, the downturn tends to be more severe, but recovery tends to be more robust. ${ }^{39}$

The policies of the Federal Reserve Board and the Bush and Obama administrations may have averted a repeat of the Great Depression and started a recovery, at least to some extent. ${ }^{40}$ Political credit for this accomplishment is not easy to garner. Since many rank-and-file voters were not old enough to experience the Great Depression, they arguably may have no appreciation of the Depression-scale hardships that may have been avoided. ${ }^{41}$

Polls showed that voters in 2010 were not naively punitive toward Obama. ${ }^{42}$ Indeed, they were much more likely to blame Bush than Obama for the dismal state of the economy in October $2010 .{ }^{43}$ Nonetheless, voters were not optimistic about the economy or their families' fiscal future. ${ }^{44}$ Exit polls in 2008 found that sixty-three percent of voters said the economy was the nation's most prevalent issue; exit polls in 2010 recorded strikingly similar report. ${ }^{45}$ In short, the public did not have confidence in the effectiveness of Obama's economic policies and was disturbed by the terrible fiscal condition of the federal government. Economic pessimism overwhelmed the few optimistic signs in the sluggish recovery.

Since the President's ability to engineer precise economic outcomes is vastly

POL. INST. (Sept. 2, 2016), http://www.epi.org/publication/missing-workers/ [https://perma.cc/ TB8Y-AK3C] (describing the concept of missing workers from the unemployment and employment rates).

39. See generally Michael D. Bordo \& Joseph G. Haubrich, Deep Recessions, Fast Recoveries, and Financial Crises: Evidence from the American Record 2 (Nat'l Bureau of Econ. Research, Working Paper No. 18194, 2012), http://www.nber.org/papers/w18194.pdf [https:// perma.cc/KAQ5-7XCP] ( $\mathrm{N}=27$ cycles since 1882 in U.S.).

40. See generally What Accounts for the Slow Growth of the Economy After the Recession?, Cong. Budget OfF. (Nov. 2012), http://www.cbo.gov/sites/default/files/43707-SlowRecovery.pdf [https://perma.cc/K676-KHBY] (describing effects of fiscal policy on economic recovery section); see also JACOBSON, supra note 30, at 230.

41. See generally A Different Look at Generations and Partisanship, PEW RES. CTR. (Apr. 30, 2015), http://www.people-press.org/2015/04/30/a-different-look-at-generations-andpartisanship/ [https://perma.cc/A6E6-H346] (analyzing young voter and generation trends); see generally Young Voters in the 2008 Election, PEw Res. CTR. (Nov. 13, 2008), http://www. pewresearch.org/2008/11/13/young-voters-in-the-2008-election/[https://perma.cc/RDM7-WCWH] (showing young voter Democratic support and voter turnout).

42. See Jacobson, supra note 22 , at 30.

43. Id.

44. See James E. Campbell, Political Forces on the Obama Presidency: From Elections to Governing, in The Obama Presidency: Appraisals And Prospects 67, 86 (Bert A. Rockman et al. eds., 2012).

45. Id. 
overrated, this Article takes the view that the electoral losses in 2010 attributable to the poor economy were largely outside of Obama's control. Nonetheless, this Article proposes some modest steps Obama could have taken in 2009-2010 to improve his handling of the economy as a political issue. ${ }^{46}$

\section{The PRESIDENT'S Job-APproval RATING}

One of the significant predictors of midterm election outcomes is the President's job-approval rating. The stronger (or weaker) the President's rating, the better (or worse) the President's party fares in Congress ${ }^{47}$ President Obama's job-approval rating, as measured by Gallup, dropped steadily from sixty-three percent during the first three months of his presidency to forty-five percent in October $2010 .^{48}$ The decline was twelve percentage points among liberals and twenty percentage points among moderates and conservatives. ${ }^{49}$ Rasmussen and other polling organizations reported similar trends. ${ }^{50}$

The decline among conservatives was difficult to prevent, given Obama's progressive agenda, but the decline among independents was a big cause for concern. Among independents, it seemed that the entrance of Obama into Washington politics had done little to reduce the partisan bickering, despite his 2008-2009 pledge of a "post-partisan presidency."51 Cable TV news channels, newspapers, drive-time radio, and other information sources portrayed the same partisan fights that independents disliked during the presidency of George W. Bush. ${ }^{52}$ As a result, independents started to become disenchanted with Obama. Obama's job-approval rating among independents remained above fifty percent through most of 2009, declined in 2010, and then fell below fifty percent throughout the fall, until the November election. ${ }^{53}$

Overall, Obama's 2010 midterm job-approval rating (forty-five percent) is

46. See infra Part XX.

47. See generally Paul Gronke \& Brian Newman, From FDR to Clinton, Mueller to ?: A Field Essay on Presidential Approval, 56 Pol. RES. Q. 501 (2003); Joseph Bafumi et al., Ideological Balancing: Generic Polls and Midterm Congressional Elections, 72 J. PoL. 705 (2010) (describing how approval ratings affect midterm loss).

48. Jeffrey M. Jones, Obama's Approval Rating at New Low in Most Recent Quarter, GALluP (Oct. 21, 2010), http://www.gallup.com/poll/143921/obama-approval-rating-new-lowrecent-quarter.aspx [https://perma.cc/5M3E-4RGE].

49. Campbell, supra note 44 , at 86 .

50. Jeffrey E. Cohen \& Costas Panagopoulos, Presidential Leadership and Public Opinion in an Age of Polarization, in The Obama Presidency: Change and Continuity 31, 31-33 (Andrew J. Dowdle et al. eds., 2011).

51. Id.

52. Richard Waterman et al., The Presidential Expectations Gap: Public Attitudes Concerning the Presidency 123 (2014).

53. Gary C. Jacobson, Polarization, Public Opinion, and the Presidency: The Obama and Anti-Obama Coalitions, in The Obama Presidency: ApPraisals AND Prospects 94-112 (Bert A. Rockman et al. eds., 2012) (Figure 5.2). 
considered "below average" for presidents since W orld War II. ${ }^{54}$ His standing was comparable to Reagan in 1982 (forty percent) and Clinton in 1994 (forty-eight percent), although better than George W. Bush in 2006 (thirty-eight percent). ${ }^{55}$

A President's job-approval rating is not as much in the control of the White House as one might think, as it is linked to economic trends and external events that are difficult for the President to control. Nonetheless, we argue below that Obama, with some modest changes in his policy agenda and implementation strategies, could have retained a stronger image among independent voters prior to his two midterm elections. ${ }^{56}$

\section{OBAMA AS A FUNDRAISER AND CAMPAIGNER}

Despite declining job-approval ratings, President Obama proved to be an effective campaign fundraiser. More than most past presidents, Obama helped raise money to support the reelection of congressional Democrats. ${ }^{57}$ The number of fund-raisers he attended far exceeded the number attended by most of his predecessors. ${ }^{58}$ Incumbent Democrats were well funded in 2010.

Tensions erupted over whether congressional Democrats should have access to the thirteen million e-mail addresses the Obama campaign compiled in $2008 .^{59}$ Obama ultimately decided to transfer the list to his private advocacy group Organizing for Action (OFA). ${ }^{60}$ Departing from the previous practices of Bill Clinton and George W. Bush, Obama and his 2008 campaign staff did not loan the list to the Democratic National Committee.$^{61}$ Serious questions were raised as to how effective OFA was during 2010 in support of either Obama's policies or Democratic candidates. ${ }^{62}$

Although Obama was a successful fund-raiser, what irritated House

54. Jacobson, supra note 22 , at 30 .

55. Id.

56. See infra Part XX.

57. Colleen McCain Nelson, Obama Ramps up Fundraising, Even on Vacation, WaLl ST. J., Aug. 9, 2014, at A4, http://www.wsj.com/articles/obama-ramps-up-fundraising-even-onvacation-1407537857 [https://perma.cc/3SCG-MDEN].

58. Id.

59. Chris Cillizza, To Urge Passage of Budget, Obama E-mails His Campaign Army, WasH. Post (Mar. 16, 2009), http://www.washingtonpost.com/wp-dyn/content/article/2009/03/15/ AR2009031501350.html [https://perma.cc/99NZ-ARSE] (stating the email list is under control of OFA); Obama Campaign Gives Database of Millions of Supporters to New Advocacy Group, NBC NEws (Jan. 28, 2013, 1:48 AM), http://investigations.nbcnews.com/_news/2013/01/28/16726913obama-campaign-gives-database-of-millions-of-supporters-to-new-advocacy-group [https://perma.cc/S3Q9-NXE8] (depicting the debate over transfer of database containing personal data on Obama voters).

60. Id.

61. See id.

62. Barbara Trish, Organizing for America, in The State of the Parties; The Changing Role of Contemporary American Parties 165, 176-77 (John C. Green et al. eds., 2011). 
Democrats was how he expended his campaign time in 2010 in support of individual candidates. ${ }^{63}$ The perception in the House was that he devoted far more time making appearances on behalf of Senate Democrats than House Democrats. President Obama's October 2010 campaign schedule lends some credence to those concerns, for he appeared locally on behalf of only two House Democrats compared to four Democratic governors and five Democratic senators. ${ }^{64}$ Many of the vulnerable House Democrats up for reelection in 2010 were freshman or sophomores who were not well known in their districts. ${ }^{65} \mathrm{~A}$ visit to their district by Obama could have been a significant boost in their visibility.

\section{THE QUALITY OF THE GOP CANDIDATES FOR CONGRESS}

The caliber of the contenders running for a congressional seat is another factor influencing midterm elections. When the economy is poor and the majority party in Congress is led by a President with low job-approval ratings, incumbents from the President's party in Congress are likely to face well-funded and highcaliber challengers. ${ }^{66}$ This is what happened in both the House and Senate in 2010.

An indicator of whether a challenger for a House seat is high caliber is whether he or she was previously an elective officeholder.$^{67}$ Novices in electoral politics tend to be weak challengers to seasoned incumbents. ${ }^{68}$ By this measure of quality the Republican challengers in 2010 were the strongest since $1968 .^{69}$

Money is not considered to have been a decisive factor in the November 2010 House and Senate elections because campaigns for both parties in nearly every competitive race were adequately financed. ${ }^{70}$ One study found that the average Democrat (Republican) running for the House benefited from $\$ 2.83$ million (\$2.35 million) in spending. ${ }^{71}$

63. Paul Kane, House Democrats Hit Boiling Point over Perceived Lack of White House Support, WASH. Post (July 15, 2010), http://www.washingtonpost.com/wp-dyn/content/article/ 2010/07/14/AR2010071406006.html [https://perma.cc/VP3T-GM2F].

64. Brian Hughes, Tale of the Tape: Obama's Campaigning a Far Cry from 2010, WasH. EXAMINER (Nov. 1, 2014), http://www.washingtonexaminer.com/tale-of-the-tape-obamascampaigning-a-far-cry-from-2010/article/2555573 [https://perma.cc/HWZ8-EURB].

65. Robert P. Watson, The Obama Presidency: A Preliminary AsSESSMEnt 131 (2012).

66. Gary C. Jacobson \& Samuel Kernell, Strategy and Choice in Congressional EleCtions 19-34 (1981).

67. See generally Pamela Ban et al., Challenger Quality and the Incumbency Advantage, http://scholar.harvard.edu/files/ellaudet/files/challenger_quality_and_the_incumbency_advantag e.pdf [https://perma.cc/C6NS-F9A2] (last visited Oct. 30, 2016).

68. Id.

69. Jacobson, supra note 22, at 37.

70. Id. at 40 .

71. Non-Party Spending Doubled in 2010 but Did Not Dictate the Results, CAMPAIGN Fin. InST. (Nov. 5, 2010), http://www.cfinst.org/press/preleases/10-11-05/Non-Party_Spending_ Doubled_But_Did_Not_Dictate_Results.aspx [https://perma.cc/38WL-NKRX]; Jacobson, supra 
Voter turnout is especially important because voter turnout is relatively low in nonpresidential elections. ${ }^{72}$ Compared to turnout rates between fifty and sixty percent when the presidency is at stake, midterm congressional elections drew consistently fewer than forty percent of eligible voters from 1990 to $2006 .^{73}$ Eligible voters in the lowest income categories are least likely to perceive differences between candidates from the two parties, which may help explain why their rates of turnout are disproportionately low. ${ }^{74}$

Obama had no control over the quality of the GOP candidates who chose to run for Congress in 2010 and 2014. The best Obama could have done was to take steps to protect his job-approval rating, especially among independent voters, since high job-approval ratings for the President may discourage good candidates of the opposing party from challenging incumbents from the President's party.

\section{EXPECTATIONS AND DISAPPOINTMENT}

The soaring rhetoric in Obama's 2008 campaign, coupled with the historic and decisive nature of his electoral victory, contributed to unrealistic public expectations about what Obama could deliver in the way of change. ${ }^{75} \mathrm{~W}$ ith the exception of the stimulus package, Obama's major domestic priorities were not acted on promptly by Congress during Obama's first year. ${ }^{76}$ Congress continued to debate health care reform, the Senate took no action after the House's 2009 action on climate change, and neither the House nor Senate took any action on immigration reform. ${ }^{77}$

The gap between performance and expectation generated massive disappointment, particularly among young people, Hispanics, women, and selfdescribed independents. ${ }^{78}$ Each of these subgroups was an enthusiastic contributor to Obama's 2008 coalition. ${ }^{79}$ As Election Day in November 2010 approached, surveys found that sixty-eight percent of Republican respondents expressed a high degree of enthusiasm about the election; only forty-four percent of

note 22 , at 40 .

72. Drew Desilver, Voter Turnout Always Drops for Midterm Elections, but Why?, PEw Res. CTR. (July 24, 2014), http://www.pewresearch.org/fact-tank /2014/07/24/voter-turnout-alwaysdrops-off-for-midterm-elections-but-why [https://perma.cc/8CDC-UVTE]; Brian G. Knight, $A n$ Econometric Evaluation of Competing Explanations for the Midterm Gap, NBER (July 2014), http://www.nber.org /papers/w20311 [https://perma.cc/9XEW-V2DW].

73. Marc J. Hetherington \& Bruce A. Larson, Parties, Politics, and Public Opinion IN AMERICA 225 (11th ed. 2010).

74. Jan E. Leighley \& Jonathan Nagler, Who Votes Now? Demographics, Issues, INEQUALITY, AND TURNOUT IN THE UNITED STATES 183-84 (2014).

75. WATERMAN ET AL., supra note 52, at 121.

76. Id. at $122-23$.

77. Id. at 122 .

78. Id. at 130-31.

79. Inside Obama's Sweeping Victory, supra note 1. 
Democrats expressed the same degree of enthusiasm. ${ }^{80}$ In close races, partyrelated differences in enthusiasm and turnout can be decisive.

In 2010, election results were far from the pre-election forecasts. Experts predicted losses for the Democratic Party in the range of twenty to fifty House seats. ${ }^{81}$ For the Senate, the forecasts for the Democrats ranged from a loss of one or two seats to a loss of four or five seats. ${ }^{82}$ The conventional wisdom was that the Democratic Party did not have enough seats at risk to produce a huge loss in the Senate. ${ }^{83}$ However, all of the statistical approaches used by experts underpredicted the losses suffered by the Democratic Party. ${ }^{84}$

\section{DIMENSIONS OF THE 2010 MASSACRE}

The 2010 results were a political earthquake of a magnitude that was far beyond what Democrats feared and Republicans hoped for. ${ }^{85}$ The Democratic Party started the evening with a 257-178 House majority. ${ }^{86}$ They lost a net sixtyfour seats in the House, allowing the Republicans to accomplish a 242-193 majority, the GOP's best showing since $1946 .^{87}$ Fifty-five incumbents were defeated, only two of them Republicans. ${ }^{88}$ Of the fifteen open seats that switched parties, fourteen switched from the Democratic to the Republican Party. ${ }^{89}$ In the Senate, the Democratic Party started out with a large 59-41 majority. ${ }^{90}$ The Republicans accomplished a net gain of six seats, reducing the Democratic margin to 53-47. ${ }^{91}$ Two Democratic incumbents were defeated and the Republicans won all four of the open seats. ${ }^{92}$

Turnout on Election Day 2010 was surprisingly high, the highest for a midterm election since $1994 .^{93}$ The shares of young and minority voters were below midterm averages while the shares of middle-aged and older voters were above midterm averages. ${ }^{94}$ An election dominated by older voters is bad news for

80. Green, supra note 9, at 136.

81. Symposium: Forecasts for the 2010 Midterm Elections, in 43 Political SCIENCE AND Politics 625, 626 (James E. Campbell ed., 2010).

82. Id. at 632 .

83. Id.

84. See infra Part IX.

85. See Jacobson, supra note 22, at 27-28.

86. Id. at 28 .

87. Id. at 27 .

88. $I d$. at 28 .

89. Id.

90. Id.

91. Id. at 27.

92. $I d$. at 28 .

93. Matthew Daly, Voter Turnout Increases from Last Midterm in 2006, WASH. PosT (Nov. 3,2010), http://www.washingtonpost.com/wp-dyn/content/article/2010/11/03/AR2010110305169. html [https://perma.cc/HQ9J-G7LG].

94. Jacobson, supra note 53, at 114-16. 
Democratic candidates, because older voters typically allocate a disproportionate share of their votes to Republican candidates. ${ }^{95}$

The voting behavior of self-described independents, as gleaned from exit polls, was a big factor in the 2010 results. Independents voted fifty-seven percent for Democratic House candidates in 2006 (thirty-nine percent for Republican House candidates) and fifty-one percent in 2008 (forty-three percent for Republicans). ${ }^{96}$ The opposite pattern unfolded in 2010 as Republican House candidates captured the independent vote fifty-six percent to thirty-seven percent. ${ }^{97} \mathrm{CNN}$ 's exit poll found that sixty-percent of 2010 voters intended their vote to signal their views of President Obama. ${ }^{98}$ In short, the Republican Party succeeded in nationalizing the 2010 midterm election, making it a referendum on Obama's performance.

Why did experts seem to under-predict the Democratic Party's losses in $2010 ?^{99}$ The horrible condition of the economy may be part of the explanation (although it was accounted for by some experts and their statistical models), but it also appears that President Obama's legislative agenda was toxic to the electoral futures of many members of his own party. ${ }^{100}$

\section{How Obama’s Policy Agenda Helped the GOP}

Recall that President Obama started his first term with a request that Congress support the TARP bailout for Wall Street and the Recovery Act's fiscal stimulus, both of which became unpopular initiatives that contributed to the GOP narrative that Obama was an old-style, big-spending liberal. ${ }^{101}$ The $\$ 1$ trillion Affordable Care Act further underscored Obama's big-government image. ${ }^{102}$ Even though (as ultimately passed) "Obamacare" lacked a single payer plan or even a public option, the White House did not discourage congressional consideration of bills that would have created a single payer or a public option. ${ }^{103}$ Moreover, Obama favored the controversial provision often demonized by the Tea Party: the individual mandate. ${ }^{104}$ The House vote on Obama's ill-fated cap and trade proposal added a significant complication to the reelection challenge faced by House Democrats from coal, oil, and manufacturing states. ${ }^{105}$

\section{Id. at 114 .}

96. Id. at 116 .

97. Id.

98. Green, supra note 9, at 134.

99. See Jacobson, supra note 22, at 28-29.

100. See infra Part X.

101. Jacobson, supra note 22, at 42-45.

102. Id. at 45-47.

103. Barbara Sinclair, Doing Big Things: Obama and the 111th Congress, in The OBAma Presidency: Appraisals and Prospects 198, 208 (Bert A. Rockman et al. eds., 2012).

104. The President's Proposal, WhiteHouse.gov (Feb. 2, 2010), https://www.whitehouse. gov/sites/default/files/summary-presidents-proposal.pdf [https://perma.cc/SG5F-FFYF].

105. Andrew Wheeler, Cap and Trade Political Kryptonite for Democrats?, Politico (Nov. 
The President's most popular legislative success was the regulatory crackdown on Wall Street (the Dodd-Frank law), but, inexplicably, he never garnered much political benefit from the initiative. ${ }^{106}$ Indeed, the public debate about Dodd-Frank seemed to reinforce the perception that Obama was antibusiness, which in turn helped open the spigots of campaign money from Wall Street to Republican challengers. ${ }^{107}$

Did Democrats in Congress do themselves any good by voting against some of the Obama agenda? Casual empiricism says they did. An examination of the House Democrats representing the forty-eight districts won by McCain in 2008 provides some insight. ${ }^{108}$ Of those who voted in favor of the ACA, only ten percent won reelection while thirty-six percent of those who voted against the ACA were reelected. ${ }^{109} \mathrm{~A}$ similar pattern exists for the stimulus package. ${ }^{110} \mathrm{O}$ the House Democrats (from McCain districts) who voted for the stimulus package, twenty-three percent won reelection while forty percent of those who voted against the stimulus won reelection. ${ }^{111}$

The cap and trade vote does not seem to follow this pattern. Two-thirds of those who voted for cap and trade were defeated, but two-thirds of those who voted against cap and trade were defeated. ${ }^{112} \mathrm{~A}$ confounding variable was the ACA vote, which overlapped with the cap and trade vote. ${ }^{113}$ Moreover, some "safe" Democrats voted against cap and trade because it was not "green" enough. ${ }^{114}$ If the focus is members from competitive seats who voted for cap and trade but against ACA, there are seven cases, and six of them were defeated. ${ }^{115}$ The one who survived (Ben Chandler of Kentucky) did so by 600 votes but then lost to the same Republican challenger (Andy Barr) in 2012. ${ }^{116}$ Cap and trade was a prominent issue in each of the seven races. ${ }^{117}$

Several analysts have employed statistical methods to investigate whether the roll-call votes cast in favor of Obama's policy agenda were associated with smaller shares of the vote for Democratic incumbents in November 2010. ${ }^{118}$ Analyses need to control for the fact that incumbent Democrats in competitive districts face more conservative voters than incumbents running in heavily Democratic districts. In fact, of the incumbent Democrats with overall moderate-

4, 2010), http://www.politico.com/arena/energy [https://perma.cc/B9NR-N6J4].

106. WATERMAN ET AL., supra note 52, at 123.

107. Jacobson, supra note 22, at 48.

108. See JACOBSON, supra note 30 , at 230-32.

109. Id.

110. Id.

111. Id.

112. Wheeler, supra note 105.

113. Id.

114. Id.

115. Id.

116. Id.

117. Id.

118. See infra notes $120-43$ and accompanying text. 
conservative voting records, fifty-four percent were defeated in 2010 while only one percent of incumbent Democrats with strongly liberal voting records were defeated. ${ }^{119}$ Thus, district characteristics need to be taken into account.

The first study of this question was released on the Internet soon after Election Day in 2010. ${ }^{120}$ The investigator, Eric McGhee, coded each Democratic incumbent in terms of how many "controversial" votes he had made in favor of four Obama proposals: Affordable Care Act, Recovery Act, cap and trade, and TARP. ${ }^{121}$ Only 3 House Democrats voted against all four measures; 18 voted for only one of them; 21 voted for two of them; 64 voted for three of four; and 128 voted for all four of them. ${ }^{122}$

The question is whether House Democrats protected themselves at the polls by voting against one or more of Obama's priorities. Using Democratic share of the 2010 vote as the dependent variable, McGhee found that each additional vote cast in favor of Obama's agenda was associated with a loss of two-thirds of one percentage point of the 2010 vote. ${ }^{123}$ McGhee's model controlled for the amount of campaign spending in each race and the normal voting pattern in each congressional district (as revealed by the 2008 House vote and the 2008 presidential vote). ${ }^{124}$ In an intriguing simulation, McGhee concludes that if all incumbent Democrats had voted against at least one of Obama's four major proposals, the number of seats lost by the Democratic Party in 2010 would have been fifty-two instead of sixty-four. ${ }^{125}$ If the four votes had never been scheduled (and thus the bills not passed), the Democrats would have lost only half as many seats (thirty-two instead of sixty-four) as they did. ${ }^{126}$

A questionable assumption of this analysis is that each of the four roll-call votes is equally controversial. ${ }^{127}$ Moreover, since the average incumbent Democrat is representing a district that voted sixty-three percent for Obama in $2008,{ }^{128}$ the analysis might be improved with some focus on competitive or Republican-leaning districts.

A second study, by Gary Jacobson, contained a targeted analysis of forty-four Republican-leaning congressional districts that were represented by an incumbent Democrat in 2009-2010. ${ }^{129}$ Six of the forty-four voted against the Recovery Act, twenty-one voted against the Affordable Care Act, and eleven voted against

119. Jacobson, supra note 22, at 48.

120. Eric McGhee, Did Controversial Roll Call Votes Doom the Democrats?, THEMONKEYCAGE.ORG. (Nov. 4, 2010), http://themonkeycage.org/2010/11/did_controversial_roll_ call_vo/ [https://perma.cc/5VT8-9737].

121. Id.

122. $I d$.

123. $I d$.

124. $I d$.

125. Id.

126. Id.

127. See id.

128. Id.

129. Jacobson, supra note 22 , at 48 . 
Dodd-Frank. ${ }^{130}$ The cap and trade vote was not analyzed. Jacobson found that voting against each of the three proposals was electorally the best strategy for this subgroup of Democrats. ${ }^{131}$ After controlling for presidential and congressional voting in 2008 (to capture the impact of district characteristics), he found that a vote for the Affordable Care Act was associated with a 4.9 percentage point decline in the incumbent Democrat's 2010 share of the vote. ${ }^{132}$ Votes for DoddFrank and the Recovery Act were associated with reductions in the Democratic vote share of 3.7 and 3.0 percentage points, respectively. ${ }^{133}$ When Jacobson enlarged the sample to include some districts without a GOP tilt, the negative effect of a vote for the Affordable Care Act persisted, but the effects of the other controversial votes were not significant. ${ }^{134}$

A limitation of this analysis is that it removes from the data numerous districts that are competitive but not tilting Republican. And the small number of districts in the analysis leads to some imprecision in the reported estimates. Like the first study, it also does not control for whether an incumbent is a freshman or sophomore and thus more vulnerable to defeat. ${ }^{135}$

A third study, by David W. Brady, Morris P. Fiorina, and Arjun S. Wilkins, compensates for the limitations in the previous studies by (1) including a relatively large sample of districts with a Democratic incumbent in 2010 who faced opposition ( $\mathrm{N}=231)$, (2) controlling for whether the incumbent was in the first or second term, and (3) accounting for the fact that the adverse effect of voting for Obama's agenda may be greatest in districts where Obama ran poorly in $2008 .{ }^{136}$ The third adjustment was accomplished by modeling interactions between roll-call votes on Obama's issues and Obama's 2008 district performance. ${ }^{137}$

The authors of the study considered only roll-call votes on the Affordable Care Act and cap and trade. ${ }^{138}$ The inclusion of the interactions led to an interesting finding: A vote for health care reform and cap and trade exerted a negative impact on an incumbent's 2010 vote share as long as the district awarded Obama less than seventy-two percent and sixty-two percent of the vote share, respectively, in 2008. ${ }^{139}$ Only in the most heavily Democratic districts, as measured by Obama's 2008 performance, was a vote for Obama's proposals neutral or beneficial for the incumbent's 2010 vote share. ${ }^{140}$

130. $I d$.

131. Id.

132. Id. at 49 .

133. Id.

134. Id.

135. See generally id.

136. David W. Brady et al., The 2010 Elections: Why Did Political Science Forecasts Go Awry?, PS: Pol. SCI. AND POL. 247, 248 (2011).

137. Id.

138. Id. at $247-50$.

139. Id. at 248 .

140. Id. 
When both proposals are included in the same model, the estimated effects are highly imprecise because of the high degree of correlation between votes for the Affordable Care Act and cap and trade. Seventy-eight percent of the incumbent Democrats voted "yes" on both measures and eight percent voted "no" on both measures. ${ }^{141}$ Five percent voted "yes" on cap and trade and "no" on health care, and nine percent voted "no" on cap and trade and "yes" on health care. ${ }^{142}$ The study's authors argue that too few Democrats voted against TARP and the Recovery Act to permit their inclusion in the analysis. ${ }^{143}$

Considering just those two votes, health care and cap and trade, Brady and his colleagues performed a simulation to determine whether the Democratic Party could have retained its majority under a scenario in which more Democrats voted against the two measures. By uniformly voting down the Affordable Care Act and elevating the number of votes against cap and trade (in those districts where Obama captured less than sixty percent of the 2008 vote), the Democratic Party could have saved forty of the sixty-four seats that it lost. ${ }^{144}$ A variety of alternative analyses by the three authors lend credence to the suggestion that House Democrats, with different roll-call voting patterns, could have retained their majority in the House.

We replicated a similar model of Democratic incumbent performance in the 2010 election using the entire sample of House incumbents $(\mathrm{N}=257)$. One version of the model used the Democratic incumbent's 2010 vote share as the dependent variable and was estimated using a method called ordinary least squares (OLS) regression; a second version used incumbent win/loss as a dichotomous dependent variable and was estimated using logistic regression. We also sought to determine the effect of three roll-call votes: the Affordable Care Act, the cap and trade bill, and the 2009 Recovery Act (the stimulus). The vote for/against each bill was treated as a dichotomous independent variable, and we created an interaction term for each bill with the 2008 Obama vote share.

As district-level control variables, we used Obama's share of the vote in the district in 2008 as well as the Democratic candidate's share of the House vote in the district in 2008. The estimated coefficients on both of these variables, as expected, are positive and statistically significant in each of the analyses that we performed. Being a freshman incumbent had, as expected, a negative and statistically significant effect on electoral results.

For the most part, we replicated the findings of previous studies with respect to the adverse effects of voting for the three bills. When a vote for each bill is analyzed separately, each vote appears to hurt the incumbent's 2008 performance. When each of the three bills is included in the same equation, the Affordable Care Act hurts incumbent performance but the other two bills are not statistically significant. If we ignore the individual bills and focus on incumbents who voted for all three of them, the effect on incumbent performance in 2008 is negative and

141. Id. at 249 .

142. Id.

143. Id.

144. Id. 
statistically significant in both the OLS and logistic models.

Overall, the key insight from all of these analyses is that Obama's legislative agenda does help explain why the Democratic Party's losses in 2010 were much greater than structural factors would have predicted. On the other hand, such analyses need to be interpreted with caution. One cannot take literally the causal notion that if more Democrats had voted against all three bills, the House majority would have been saved. The flaw in that inference is that other factors would not likely have been constant.

For example, if Obama's signature domestic initiatives had been ignored or rejected by a Democratic Congress, his job-approval ratings likely would have fallen to even lower levels than were observed, and those dismal ratings would have put congressional Democrats at even greater risk of defeat in 2010 . We would also need to reconsider whether Obama would have been reelected in 2012 if he had accomplished none of his major first-term domestic priorities. Indeed, Obama might have been challenged by a prominent Democrat in the 2012 Democratic primary, like President Jimmy Carter was challenged by Ted Kennedy in $1980 .{ }^{145}$ Nonetheless, it does appear that Obama's agenda (ACA and, to a lesser extent, cap and trade and fiscal stimulus) contributed to the defeat of some of his co-partisans in the House of Representatives.

\section{OBAma AND THE 2014 MidTERm ELECTION}

Soon after President Obama was reelected in November 2012, the focus of the parties shifted to the November 2014 midterm election. Unlike 2010, where the big story was the GOP takeover of the House, the issue in 2014 was the fate of the Senate. We begin the discussion of this issue with the structural aspects of the 2014 election and then explore the complications faced by Obama and why Obama's job approval ranking slumped.

One structural aspect is the role of swing districts. Swing districts in the House can be defined as those where historical voting patterns range from +5 percentage points for the Democratic candidate to +5 percentage points for the Republican candidate. In 1998 there were 164 swing seats, the remainder being solidly Republican (148) or solidly Democratic (123). ${ }^{146}$ By 2014 the number of swing seats in the House had dwindled to ninety, the remainder being solidly Republican (186) or solidly Democratic (159). ${ }^{147}$ The fewer seats in play partly reflected redistricting changes in 2010 (often engineered by Republican officials) and partly demographic changes and migration that put more districts into safe territory for one party or the other. ${ }^{148}$

145. Alan I. Abramowitz, DisapPearing Center: Engaged Citizens, Polarization, And AMERICAN DEMOCRACY 108 (2010).

146. Charlie Cook, The Republican Advantage, NAT'L. J., Apr. 13, 2014, at 14.

147. Id.

148. Patrick O'Connor, House Districts Keep Getting Safer, WALl ST. J., July 29, 2013, at A4, http://www.wsj.com/articles/SB 10001424127887324170004578634270313876136 [https://perma.cc/YKW7-5X8Q]. 
Among the ninety swing seats in 2014, only a small subset was genuinely in play. ${ }^{149}$ Based on 2012 presidential election results, only seventeen were districts held by the GOP but carried by Obama; only nine were districts held by the Democrats but carried by Romney. ${ }^{150}$ The Republican Party made a serious effort to challenge about twenty-five of the thirty-six incumbent Democrats holding seats where Obama won fifty-five percent or less of the vote in $2012 .{ }^{151}$ The Democratic Party chose to challenge seriously only about six GOP incumbents, all holding a district that had produced a strong Obama vote in $2012 .{ }^{152}$ As a result, the structure of the 2014 House contests seemed unlikely to produce a Democratic House majority, since there were not enough vulnerable and contested Republican incumbents to shift the balance of power to the House Democrats. The real question was whether the Republican Party would retain its margin or increase it.

The Senate situation was entirely different, because the Democratic Party was defending twenty-one incumbents compared to only fifteen for the Republican Party. ${ }^{153}$ And many of the incumbent Democrats were running for reelection in GOP-leaning states.

Economic policy again was an important issue. As the economic recovery accelerated in 2013-2014, ${ }^{154}$ one could reasonably expect that President Obama and the Democratic Party would reap some political benefit from the declining rate of unemployment, the rise in consumer confidence, the surge in car and home sales, and the rising stock market. ${ }^{155}$ But, it simply did not work out that way, and in fact this period proved to be highly unproductive for the Obama White House and their allies in Congress.

Part of the problem was that gains in the "jobs-to-people" ratio were much more anemic than the substantial declines in the official rate of unemployment, ${ }^{156}$ suggesting that the job-producing performance of the economy was damaged.

149. Karl Rove, Can the Democrats Retake the House in 2014?, WALl St. J., Aug. 15, 2013, at A13, http://www.wsj.com/articles/SB10001424127887324823804579012480016306504 [https:// perma.cc/5R7Q-S8X7].

150. Ronald Brownstein, More Paralysis Ahead, NAT'L. J., Oct. 25, 2014, at 1.

151. Id.

152. Id.

153. U.S. Federal Election Commission, Federal Elections 2010: Election Results for the U.S. Senate and the U.S. House or Representatives (July 2011), http://www.fec.gov/pubrec/fe2010/ federalelections2010.pdf [https://perma.cc/X3BB-VSMB].

154. Jonathan Weisman, Economic Recovery Yields Few Benefits for the Voters Democrats RelyOn, INT'LN.Y.TIMES, May 20, 2014, at A14, http:/www.nytimes.com/2014/05/20/us/politics/ economic-recovery-is-leaving-major-democratic-constituencies-behind.html?_r=0 [https://perma.cc/RS7V-LB54].

155. See generally Council of Econ. Advisers, The Economy in 2014 (Dec. 23, 2014), https://www.whitehouse.gov/sites/default/files/docs/2014-12-year-in-review-update.pdf [https://perma.cc/2HEM-KLK3].

156. The Employment Situation-December 2014, Bureau Lab. Stat. 2 (Jan. 2015), http://www.bls.gov/news.release/archives/empsit_01092015.pdf[https://perma.cc/9BAB-ASC3]. 
Another problem was that the gains in employment and earnings in 2013-2014 were not particularly impressive for key subgroups in Obama's base: women, young people, blacks, and households with incomes less than $\$ 30,000$ per year. ${ }^{157}$ Wages for the new jobs in the Obama economy were also reported to be far less than wages for the jobs that were destroyed by the Great Recession, and thus income growth in 2013-2014 was slight. ${ }^{158}$ Overall, while the economy was recovering, it was not generating much enthusiasm for Obama or the Democrats in Congress.

\section{ISSUE DISTRACTIONS IN 2013-2014}

As the Obama White House sought to focus on the many positives about the recovery and the President's ambitious second-term agenda, public attention was diverted to a series of distracting issues that complicated the picture. Since most of these issues were not easy to resolve, they created additional uncertainty about Obama's effectiveness and ample raw material for partisan attacks by congressional Republicans.

One of the nagging old issues was the proposed north-south Keystone pipeline, which was intended to transport oil from the Canadian tar sands in Alberta to refineries in the Gulf of Mexico. ${ }^{159}$ Since the United States was rapidly consuming less Canadian oil (due to advances in U.S. oil production), the Canadians planned to use the pipeline to exploit lucrative export markets in Europe and Asia. ${ }^{160}$ Oil producers in the Bakken region of North Dakota would also use the pipeline. ${ }^{161}$ For refiners in Louisiana and Texas, the Keystone pipeline promised significant new business. ${ }^{162}$

Obama was cross-pressured by business interests and the Canadian government on one side and organized environmentalists (who saw development of the tar sands as a source of environmental pollution) on the other side. ${ }^{163}$ Despite numerous studies of the Keystone issue during Obama's first term, the

157. Weisman, supra note 154.

158. See Annie Lowrey, Recovery Has Created Far More Low-Wage Jobs Than Better-Paid Ones, N.Y. Times, Apr. 28, 2014, at B4, http://www.nytimes.com/2014/04/28/business/economy/ recovery-has-created-far-more-low-wage-jobs-than-better-paid-ones.html [https://perma.cc/L6P5F7FX].

159. See Jacques Leslie, Shipping Crude Oil by Rail: New Front in Tar Sand Wars, YALE ENV'T 360 (Dec. 5, 2013), http://e360.yale.edu/feature/shipping_crude_oil_by_rail_new_front_ in_tar_sands_wars/2717/[https://perma.cc/3WQZ-XTB2].

160. See David LaGesse, Is Canadian Oil Bound for China Via Pipeline to Texas?, NAT'L GEOGRAPHIC (Aug. 20, 2011), http://news.nationalgeographic.com/news/energy/2011/08/110819keystone-xl-canadian-oil-and-chinese-market/ [https://perma.cc/4GAS-FSSR].

161. See Kirk Eggleston, How the Keystone XL Pipeline Would Impact the Bakken, BAKKEN SHALE (Nov. 18, 2014) http://bakkenshale.com/bsp-news/news/how-the-keystone-xl-pipelinewould-impact-the-bakken [https://perma.cc/D9G7-98SH].

162. LaGesse, supra note 160.

163. Id. 
issue was left unresolved until his second term. Democratic senator Mary Landrieu of Louisiana was up for reelection in November 2014, and the President's handling of the Keystone issue did not help her with her constituents. ${ }^{164}$ By refusing to use his executive power to approve or disapprove the pipeline, Obama opened up the issue for a bipartisan group of pro-pipeline members in Congress. ${ }^{165}$

The House easily passed bills calling for approval of the pipeline, but, consistent with Obama's request, Senate majority leader Harry Reid blocked a vote on the issue in the Senate during 2013 and 2014. ${ }^{166}$ The Obama-Reid position further undermined Landrieu, who was challenged for reelection by Republican congressman Bill Cassidy. ${ }^{167}$

Another disturbing issue was the inability of the U.S. Veterans Administration (VA) to efficiently process requests for medical and other forms of assistance by the thousands of returning veterans from Iraq and Afghanistan. ${ }^{168}$ The public did not blame President Obama personally for the poor quality of the VA's public administration, but distressing stories about the VA's incompetence reinforced cynicism about the federal government and drew media attention away from the improving economy and Obama's second-term agenda.

One of the new issues that the Obama administration confronted was the emergence of the deadly Ebola virus in the United States, the first case being reported in September 2014 and a total of four cases by December 2014. ${ }^{169}$ Within a few months of the onset of press coverage, ninety-eight percent of Americans had heard or read about the frightening virus, and there was much debate as to whether the federal government was responding properly to the potential emerging crisis. ${ }^{170}$ Some critics argued that the Obama administration should have promptly instituted a travel ban from areas (e.g., regions of Africa) where the viral disease was widespread. ${ }^{171}$ Backed by public health experts, the

164. See Alex Rogers, The Politics Behind Mary Landrieu's Pipeline Power Play, TIME(Nov. 13, 2014), http://time.com/3583553/the-politics-behind-landrieus-pipeline-power-play/ [https:// perma.cc/VCN6-FPYN].

165. See id.

166. Stephanie Condon, Can a Keystone Pipeline Vote Help Mary Landrieu?, CBS NEws (Nov. 18, 2014), http://www.cbsnews.com/news/can-a-vote-on-the-keystone-pipeline-help-marylandrieu/ [https://perma.cc/J5KR-QKQD].

167. Id.

168. See Scott Bronstein et al., Veterans Dying Because of Health Care Delays, CNN (Jan. 30, 2014), http://www.cnn.com/2014/01/30/health/veterans-dying-health-care-delays/ [https://perma.cc/CWQ8-APN3].

169. 2014 Ebola Outbreak in West Africa, CTR. FOR Disease COnTrol, http://www.cdc. gov/vhf/ebola/outbreaks/2014-west-africa/case-counts.html [https://perma.cc/J8UM-6GKA].

170. Charlie Cook, Questions and Possible Answers, NAT'L J., Oct. 25, 2014, at 12; Janet Hook, GOP Holds Better Hand Amid Wild Cards, WALl St. J., Oct. 15, 2014, at A4.

171. See Bart Jansen, Lawmakers Urge an Ebola Travel Ban, Obama Opposed, USA TODAY (Oct. 17, 2014), http://www.usatoday.com/story/news/nation/2014/10/17/ebola-travel-ban-obamacdc-faa/17433901/ [https://perma.cc/P223-ZGH6]. 
President decided against a ban, but the controversy erupted immediately prior to the 2014 midterm elections. ${ }^{172}$

Normally, international issues are not central to U.S. elections, but in 2014 they were significant. Events abroad raised unusually difficult challenges for Obama, creating situations that did not buttress his image as an influential or effective leader. ${ }^{173}$ Russia's leader Vladimir Putin deftly sidestepped accountability for the Malaysian airliner that was shot down by Russia-supplied forces and Putin later ignored the West as he persistently advanced Russian interests in the conflict with the Ukraine and the European Union. ${ }^{174}$ Numerous questions were raised about the Bowe Bergdahl prisoner swap engineered by the Obama administration. ${ }^{175}$ A bloody new war broke out in Gaza between Israel and Hamas. ${ }^{176}$ And the Middle East extremist group ISIS conquered a large swath of Iraq, forcing a reluctant Obama to resort to air strikes. ${ }^{177}$ The foreign policy challenges were quite difficult to resolve and thus planted more seeds of doubt about the competence of the Obama administration. ${ }^{178}$

Surveys also revealed that the public was increasingly concerned about the "gridlock" in Washington, D.C. ${ }^{179}$ Respondents were asked whether they prefer an elected official who compromises in order to gain consensus or sticks to his or her positions. ${ }^{180}$ A 2010 survey showed that fifty percent preferred compromise; forty-two percent favored firmness. ${ }^{181}$ By 2014, sentiments shifted toward compromise, with fifty-seven percent expressing that preference. ${ }^{182}$ After the big economic issues, respondents saw breaking political gridlock as the second most important issue facing the country. ${ }^{183}$ While respondents tended to blame congressional Republicans more than Democrats for gridlock, they did not give Obama high marks as an agent of effective compromise and consensus building. ${ }^{184}$

President Obama started his second term with a job-approval rating of fifty-

172. Id.

173. William A. Galston, A World of Trouble for Obama, WALL St. J., Sept. 13, 2014, at A11; James Oliphant, Presidential Paralysis, NAT'L. J., June 14, 2014, at 24.

174. Galston, supra note 173.

175. See, e.g., Oliphant, supra note 173.

176. Gaza Conflict: Israel and Palestinians Agree Long-Term Truce, BBC NEws (Aug. 27, 2014), http://www.bbc.com/news/world-middle-east-28939350 [https://perma.cc/VD3S-SZXW].

177. See Helena Cooper et al., Obama Allows Limited Airstrikes on ISIS, N.Y. TIMES, Aug. 8, 2014, at A1.

178. Cook, supra note 170; Andrew Kohut, How Americans View an Unruly World, WALL ST. J., Aug. 5, 2014, at A11.

179. See Gerald F. Seib, Voters Show Early Signs of Punishing Political Gridlock, WALL ST. J., Oct. 21, 2014, at A4.

180. Id.

181. Id.

182. Id.

183. Id.

184. Id. 
two percent, much lower than where he started his first term (close to seventy percent) and without the significant bump that previous reelected presidents experienced. ${ }^{185}$ Nonetheless, Obama's standing seemed strong enough to be respected among congressional Democrats and Republicans from competitive districts and states.

Cashing in on an early concession from House Speaker John Boehner, Obama worked the Congress in late 2012 to accomplish repeal of the Bush tax cuts for high-income households. ${ }^{186} \mathrm{He}$ then planned to pursue a much bigger agenda: reform federal immigration law and, somewhat quietly, a grand fiscal deal with Boehner that covered taxes and entitlement programs such as Medicare. ${ }^{187}$

On December 14, 2012, Obama reordered his priorities in the wake of the shooting of twenty children and six school officials at Sandy Hook Elementary School in Newtown, Connecticut. ${ }^{188}$ The President placed gun control above his other legislative initiatives, a decision that was clearly opportunistic, as he had given little priority to gun control during his first term and chose not to elevate the issue as a priority in his 2012 reelection campaign. ${ }^{189}$

Capitalizing on the public outcry, Obama requested that Congress enact universal background checks, limits on high-capacity ammunition, an assaultweapons ban, and more severe penalties for people who buy guns and then sell them illegally on the black market. ${ }^{190}$ A bipartisan proposal to expand background checks on gun purchasers was advanced by Republican Pat Toomey and Democrat Joe Manchin, both respected pro-gun conservatives. ${ }^{191}$ The measure appeared to have the best chance of passage but ultimately fell six votes short of

185. See generally James D. King \& James W. Riddlesperger, The 2012-2013 Transition to the Second Obama Administration, in The 2012 Presidential Election: Forecasts, Outcomes, And Consequences 144 (Amnon Cavari et. al eds., 2014).

186. Mark Lander \& John Cushman Jr., Obama Pushes Tax Cut Extension That Excludes Wealthiest, N.Y. TiMES (Jul. 9, 2012), http://www.nytimes.com/2012/07/10/us/politics/obamapushes-tax-cut-extension-that-excludes-wealthiest.html [https://perma.cc/544T-X27W].

187. Peter Wallsten et al., Obama's Evolution, Behind the Failed 'Grand Bargain' on the Debt, WASH. Post (Mar. 17, 2012), https://www.washingtonpost.com/politics/obamas-evolutionbehind-the-failed-grand-bargain-on-the-debt/2012/03/15/gIQAHyyfJS_story.html [https://perma.cc/GLM4-79U7].

188. King \& Riddlesperger, supra note 185, at 143.

189. See Phillip Rucker \& Sari Horwtiz, On Gun Control, Obama's Record Shows an Apparent Lack of Political Will-Until Now, WASH. Post (Dec. 23, 2012), https://www. washingtonpost.com/politics/on-gun-control-obamas-record-shows-an-apparent-lack-of-politicalwill--until-now/2012/12/23/913a3626-4937-11e2-ad54-580638ede391_story.html [https://perma.cc/Y2SK-PXRG].

190. Ed O'Keefe \& Philip Rucker, Gun Control Overhaul Is Defeated in Senate, WASH. Post (Apr. 17, 2013), https:// www.washingtonpost.com/politics/gun-control-overhaul-is-defeated-insenate/2013/04/17/57eb028a-a77c-11e2-b029-8fb7e977ef71_story.html [https://perma.cc/2XHFKWA2].

191. Ross K. Baker, Is Bipartisanship Dead? A Report From the Senate 42 (2014). 
the required sixty votes. ${ }^{192}$ Manchin believed that the measure's chances of passage vanished when the NRA announced that it would "score the vote." 193

Four Republican senators (Toomey, John McCain, Susan Collins, and Mark Steven Kirk) voted in favor of the expanded background checks, but an equal number of Senate Democrats voted against it (Mark Begich, Mark Pryor, Max Baucus, and Heidi Heitkamp) ${ }^{194}$ Three of the defecting Democrats were up for reelection in 2014. ${ }^{195}$

Obama's gun-control initiative died in the Senate when none of his requested reforms could reach the required sixty-vote threshold. ${ }^{196}$ His proposal was never taken up in the House, where passage would have been even more difficult, so he was forced to resort to a few "small ball" executive actions (e.g., sharing of information on firearm violence among federal agencies). ${ }^{197}$ Thus, Obama's first legislative initiative in his second term was a stark failure, an outcome that "was predictable based on the issue's history and the ideological polarization on Capitol Hill." ${ }^{\prime 198}$ Making things worse, the setback bolstered a second-term narrative that questioned Obama's effectiveness as a domestic policymaker. ${ }^{199}$

Moreover, the failure of gun control frustrated Obama's base and energized his partisan opponents. Some critics argue that the entire effort squandered political capital that Obama should have invested on immigration reform, the legislative priority that he had some electoral mandate to pursue, since it was highlighted in his 2012 campaign against Romney. ${ }^{200} \mathrm{~W}$ ith hindsight, some have suggested that the gun-control initiative may have moved better in the Senate without White House priority, since Obama's visibility on the issue energized the opposition and helped NRA bolster its support. ${ }^{201}$

Obama's standing was rejuvenated to some extent later in 2013 when he forced House Republicans to capitulate on the controversial sixteen-day

192. Heidi Przybyla \& James Rowley, Senate Defeats Background-Check Plan, Imperiling Gun Bill, BloomBerg (Apr. 17, 2013, 9:50 PM), http://www.bloomberg.com/news/articles/201304-17/senate-defeats-background-check-plan-imperiling-gun-bill [http://perma.cc/55FB-39PJ].

193. BAKER, supra note 191, at 42.

194. Senate Vote 97-Defeats Manchin-Toomey Background Checks Proposal, ProPuBLICA (Apr. 17, 2013, 4:04 PM), https://projects.propublica.org/represent/votes/113/senate/1/97 [https:// perma.cc/A8JP-WGHS].

195. Larry J. Sabato \& Kyle Kondik, 2014 Senate Preview: Can Republicans Finally Turn Potential Into Reality?, U. of VA. CTR. For Pol.: SABAto's Crystal Ball (Nov. 29, 2012), http://www.centerforpolitics.org/crystalball/articles/2014-senate-preview-can-republicans-finallyturn-potential-into-reality/ [https://perma.cc/KGS7-2NCN].

196. O'Keefe \& Rucker, supra note 190.

197. King \& Riddlesperger, supra note 185 , at 138-39.

198. Id. at 139 .

199. Id. at 138-39.

200. George E. Condon Jr., Obama's Lost Year, NAT'L. J., Nov. 9, 2013, at 38.

201. Ryan Lizza, Four Reasons Why the Gun-Control Bills Failed, New Yorker (Apr. 18, 2013), http://www.newyorker.com/news/news-desk/four-reasons-why-the-gun-control-bills-failed [https://perma.cc/AY56-6XC8]. 
government shutdown. ${ }^{202}$ Before he could capitalize on the improved standing, the botched rollout of the Affordable Care Act sent his job-approval ratings to new lows. ${ }^{203}$ At roughly the same time, the Obama administration was challenged by the burgeoning civil war in Syria, and the President's response was widely criticized as indecisive. ${ }^{204}$

\section{The Health Care Website Fiasco}

Healthcare, one of Obama's legislative priorities, proved to be another challenge for the administration and Democratic Party. Although Obama was able to move the Affordable Care Act through Congress, implementation of the complex piece of legislation led to some major snafus. The President and his advisors seemed slow to realize that competent implementation of the ACA required a team with different skills than the team required for passing the law. ${ }^{205}$ As a result, the Obama administration exhibited symptoms of weak public administration, which supplied the Republicans political ammunition and further complicated the President's quest to build public confidence in the ACA. ${ }^{206}$

Obama struggled to nominate an implementation team with qualified leadership. The President was slow to build his executive team at the critical Department of Health and Human Services (HHS). After much delay, Obama nominated Kathleen Sebelius as his HHS secretary. ${ }^{207}$ She stepped down in 2014 after the worst of the ACA implementation problems were being fixed and was succeeded by Sylvia Mathews Burwell. ${ }^{208}$

The most revealing indication of the White House's neglect of the ACA

202. Jonathan Weisman \& Ashley Parker, Shutdown is Over, N.Y. TimEs, Oct. 17, 2013, at A1,http://www.nytimes.com/2013/10/17/us/congress-budget-debate.html [https://perma.cc/A8QPGLG7].

203. John B. Judis, Here's Why the Democrats Got Crushed-and Why 2016 Won't Be a Cakewalk, New RePuBlic (Nov. 5, 2014), https://newrepublic.com/article/120138/2014-electionresults-heres-why-democrats-lost-senate-gop [https://perma.cc/5WLR-M544].

204. Gerald F. Seib, 2014 Made Simple: Democrats Lose Edge on Economic, Foreign Policy, WALL ST. J. (Oct. 14, 2014), http://www.wsj.com/articles/democrats-lose-edge-on-economicforeign-policy-1413215363 [https://perma.cc/XC3H-8VGH].

205. See Obamacare: Memo Reveals Health Care Advisor Warned W.H. Was Losing Control 3 Years Ago, CBS News (November 4, 2013, 1:07 PM), http://www.cbsnews.com/news/obamacarememo-reveals-health-care-adviser-warned-wh-was-losing-control-3-years-ago/ [https://perma.cc/6GEY-64MN].

206. $I d$.

207. Dam Amira, Obama Nominates Kathleen Sebelius for Health Secretary, NYMAG.CoM: DAILY INTELLIGENCER (Mar. 2, 2009, 11:05 AM), http://nymag.com/daily/intelligencer/2009/03/ obama_nominates_kathleen_sebel.html [https://perma.cc/5MJ3-NJW9].

208. Louise Radnofsky, Burwell Confirmed as Health and Human Services Secretary Sylvia Mathews Burwell Now Set to Succeed Kathleen Sebelius, WaLL ST. J. (June 5, 2014), http://www. wsj.com/articles/burwell-confirmed-as-health-and-human-services-secretary-1401992445 [https://perma.cc/KG9Y-JNPY]. 
implementation challenge was the mishandling of the leadership of the Centers for Medicare and Medicaid Services (CMS). Obama did not nominate a candidate to lead CMS until April 2010 when he nominated Dr. Donald Berwick. ${ }^{209}$ Though he was experienced in the medical field, Berwick lacked management experience at a public agency. ${ }^{210}$ Senate Republicans saw nothing but partisan opportunity in the Berwick nomination. ${ }^{211}$ Within two months of the official Berwick nomination, all forty-two Republicans in the Senate signed a letter to the President requesting withdrawal of the Berwick nomination. ${ }^{212}$ Desperate to have some leadership, the White House stubbornly made a "recess appointment," which allowed Berwick to serve as CMS administrator without Senate confirmation for a brief period, from July 2010 to December 2011. ${ }^{213}$ After Berwick departed CMS, Obama did not accomplish a successful Senate confirmation of a CMS administrator until May 2013, more than four years after he was inaugurated. ${ }^{214}$ Thus, President Obama relied upon a troubled agency without effective leadership to implement his signature initiative, and his political opponents in Congress happily exploited the forthcoming mishaps at CMS for partisan gain.

\section{The 2013 Drop In Approval Ratings}

Overall, 2013 proved to be an unproductive and demoralizing year for President Obama, as nothing he pledged to do with Congress in 2013 was actually accomplished. ${ }^{215}$ His job-approval ratings slipped into the low forties. ${ }^{216}$ In fact, Obama started his sixth year in office with a job-approval rating lower than all other presidents (except George W. Bush) since modern polling began in the 1930 s. $^{217}$

209. Robert Pear, Medicare and Medicaid Chief, Never Confirmed by Senate, Is Stepping Down, N.Y. Times, Nov. 24, 2011, at A26, http://www.nytimes.com/2011/11/24/health/policy/drdonald-m-berwick-resigns-as-head-of-medicare-and-medicaid.html?_r=0 [https://perma.cc/33YFLDVZ].

210. Harold Pollack \& Christopher Lillis, The Donald Berwick Predicament, KAISER HEALth NEws (Mar. 11, 2011), http://khn.org/news/031111pollack/ [https://perma.cc/C4TV-GE7U].

211. See id.

212. Id.

213. Robert Pear, Obama to Bypass Senate to Name Health Official, N.Y. TiMES, July 7, 2010, at A11, http://www.nytimes.com/2010/07/07/health/policy/07recess.html [https://perma.cc/J5YL9DGZ].

214. Jennifer Haberkorn \& Paige Winfield Cunningham, Marilyn Tavenner Approved by Senate for CMS Post, PoLITICO (May 15, 2013), http://www.politico.com/story/2013/05/marilyn -tavenner-cms-91438.html [https://perma.cc/YTQ6-4NDG].

215. Condon, supra note 200, at 38.

216. Presidential Approval Ratings-Barack Obama, GALLuP, http://www.gallup.com/ poll/116479/barack-obama-presidential-job-approval.aspx [https://perma.cc/2U9Q-SL87] (last visited Oct. 30, 2016).

217. Neil King Jr. \& Patrick O’Connor, Poll Finds Americans Anxious Over Future Obama's 
Among the key group of self-described independents, Obama's job approval was slumping into the range of thirty to forty percent. ${ }^{218}$ (Although he had defeated McCain among independents in 2008, he lost independents to Romney by a five percent margin. ${ }^{219}$ ) Nor was Obama retaining the confidence of the millennial generation. His job-approval rating among eighteen-to-thirty-four-year olds declined from seventy percent in early 2009 to forty-nine percent in early 2014. ${ }^{220}$

The sharp decline in Obama's ratings in 2013 is partly attributable to lingering economic insecurities (even though the economic recovery was continuing), but the botched rollout of the ACA was also a significant contributor. ${ }^{221}$ Obama had also set expectations for legislative progress on an agenda that did not move (i.e., gun control, immigration reform, and a grand fiscal deal).

President Obama's standing slid further in 2014, prior to the November 2014 general election. ${ }^{222}$ His overall job-approval rating was recorded at forty-one percent in both April and June 2014, but the more ominous sign was the asymmetric distribution of intense feelings: Of those who disapproved of Obama's performance, forty percent did so "strongly;" among those who approved, only twenty-three percent did so "strongly."223 The year 2014 was a particularly bad one for Obama in foreign policy, where his job-approval rating slipped to thirty-seven percent that June. ${ }^{224}$ Much was written about his inability to control unsettling events around the world. ${ }^{225}$

The growing disapproval of Obama in 2013-2014 was not rooted in public

Performance, WALl ST. J. (Jan. 28, 2014), http://www.wsj.com/articles/SB1000142405270230 3277704579347030062444064 [https://perma.cc/F6B4-DVFW].

218. Daniel Henninger, Obama's State of Disunion, Wall St. J., Jan. 29, 2014, at A11, http://www.wsj.com/articles/SB 10001424052702304428004579350953723724542 [https://perma.cc/K7JB-KL6V].

219. Andrew Kohut, The Demographics Behind the Democrats'2014 Troubles, WaLl St. J., March 31, 2014, at A13, http://www.wsj.com/articles/andrew-kohut-how-americans-view-anunruly-world-1407195747 [https://perma.cc/D8TQ-8ULT].

220. Id.

221. See Dan Balz \& Peyton M. Craighill, Obama's Ratings Tumble After Health-Care Flaws, WASH. PosT (Nov. 19, 2013), https://www.washingtonpost.com/politics/obamas-ratings-tumbleafter-health-care-flaws/2013/11/18/c9cdbc2c-507c-11e3-9fe0-fd2ca728e67c_story.html [https://perma.cc/9C4T-ENY9].

222. See Charlie Cook, Early Days Yet, CooK Pol. ReP. (May 6, 2014), http://cookpolitical. com/story/7196 [https://perma.cc/KHY8-4AWV].

223. Id.

224. Patrick O'Connor, Poll Shows Erosion in President's Support, Wall St. J., June 18, 2014, at A4, http://www.wsj.com/articles/poll-shows-erosion-in-presidents-support-1403064301 [https://perma.cc/K292-AVX6].

225. See, e.g., Ross Douthat, Grading Obama's Foreign Policy, N.Y. Times (May 17, 2014), http:/www.nytimes.com/2014/05/18/opinion/sunday/douthat-grading-obamas-foreign-policy.html [https://perma.cc/55LM-5R9H]. 
disagreement with the themes he was emphasizing in his public appearances: job creation through new spending on infrastructure, early childhood education, refinancing student loans, a higher minimum wage, and fair pay for women. Those themes brought a heightened degree of unity between Obama and the Senate Democrats who were up for reelection in 2014. And the public continued to side with Obama on many domestic issues: education, health care, immigration, and the environment. ${ }^{226}$ Nor was Obama's problem any public preference for the performance of the two parties in Congress; the House GOP leadership and Senate Democratic leadership were both sporting disapproval ratings over seventy percent. ${ }^{27}$

Many Americans were nuanced in their assessment of Obama. He was considered "compassionate" (fifty-eight percent) and "a good communicator" (sixty-eight percent). ${ }^{228}$ The public was evenly divided on whether his administration was "competent," but fifty-four percent no longer felt that Obama "[was] able to lead the country and get the job done." ${ }^{229}$ About forty-one percent of respondents felt in June 2014 that his performance was getting worse; only fifteen percent felt it was getting better. ${ }^{230}$ On a key indicator about the President's ability to be effective (whether Obama is "able to get things done"), his approval rating declined from fifty-seven percent in January 2013 to fortythree percent in early 2014, and it never rebounded prior to the November 2014 election..$^{231}$

\section{GOP STRATEGY IN 2014}

Given Obama's difficulties in 2013 and early 2014, the midterm election in November was shaping up as an enticing opportunity for the GOP. With Boehner's House majority looking fairly secure, the national Republican Party set its sights on control of the Senate.

Before the primaries in 2014, an internal GOP conflict surfaced over whether to run candidates favored by the Tea Party or stick with candidates favored by traditional leaders of the GOP. ${ }^{232}$ Business leaders and national leaders of the Republican Party were convinced that the party had missed an opportunity to seize control of the Senate in 2012 by nominating several Senate candidates who were too conservative to win a general election or were too inexperienced to defeat an entrenched Democratic incumbent. ${ }^{233}$

226. O’Conner, supra note 224.

227. Cook, supra note 222.

228. Kohut, supra note 219.

229. O'Connor, supra note 224.

230. Id.

231. Kohut, supra note 219.

232. Janet Hook, Tea Party Faces Test of Its Clout in Primaries, Wall St. J., Feb.25, 2014, at A1, http://www.wsj.com/articles/SB10001424052702304834704579401480582653814 [https:// perma.cc/CT7Q-R3Y2].

233. Id 
Business leaders were also irritated that Tea Party conservatives ignored their warnings that closing the government in the fall of 2013 (and risking financial default) would hurt Boehner, the Republican Party, and the Tea Party. ${ }^{234}$ They pointed out that the shutdown ultimately accomplished nothing for conservatives. ${ }^{235}$

The Tea Party and many conservative House Republicans entertained doubts about Speaker John Boehner, seeing him as a compromiser rather than a principled conservative. Representative Thomas Massie of Kentucky, for example, often voted against Boehner-led priorities and spearheaded an unsuccessful coup of Boehner as Speaker. ${ }^{236}$ Massie was connected to a group of a dozen or so devout House conservatives who were not reluctant to use their voting power as a bloc to deny Boehner legislative control. ${ }^{237}$ The group effectively forced Boehner to seek Democratic votes for disaster relief after Superstorm Sandy, for the Violence Against Women Act, and for extension of the Bush tax cuts for people making less than $\$ 400,000$ a year. ${ }^{238}$

By 2013-2014 the Tea Party had suffered some image blows, including widespread disapproval of the government shutdown in the fall of $2013 .{ }^{239}$ The share of the public who were sympathetic with the Tea Party was declining and the rate of participation in Tea Party rallies and protests was down. ${ }^{240}$ Nonetheless, core membership in the national Tea Party groups remained high (over 500,000), with forty-two percent of overall membership in the Southern states. ${ }^{241}$ Many more Americans were sympathetic with the positions of the Tea Party, especially as they related to illegal immigration and the high rate of federal spending. ${ }^{242}$

The National Republican Senatorial Committee collaborated with the U.S. Chamber of Commerce to identify, recruit, and support the most promising possible candidates for Senate races. In the Republican primaries, potential Senate candidates from the more conservative wing of the GOP were bypassed or defeated in Georgia, Iowa, Kentucky, North Carolina, Oklahoma, and

234. Patrick O’Connor, Freshmen GOP Lawmakers Revel in Maverick Power, WaLL St. J., Aug. 2, 2013, at A1, http://www.wsj.com/articles/SB1000142412788732330000457855988334 8741740 [https://perma.cc/XM9F-J6PY].

235. See Molly Ball, Republicans Shut Down the Government for Nothing, AtLANTIC (Oct. 16, 2013), http://www.theatlantic.com/politics/archive/2013/10/republicans-shut-down-thegovernment-for-nothing/280611/ [https://perma.cc/V52U-M6N4].

236. O'Connor, supra note 234.

237. $I d$.

238. Id.

239. Devin Burghart, The Status of the Tea Party Movement - Part Two, Inst. FOR RES. AND EDUC. ON HuM. RTS. (2014), http://www.irehr.org/2014/01/21/status-of-tea-party-by-the-numbers/ [https://perma.cc/EF37-URQY].

240. Id.

241. Id.

242. Id. 
Oregon. $^{243}$

The Tea Party and allied groups (e.g., FreedomWorks for America, Senate Conservatives Fund, Tea Party Patriots Citizens Fund, and Club for Growth) made a determined, multimillion-dollar effort to oust Senator Thad Cochran, the incumbent establishment Republican from Mississippi. ${ }^{244}$ The U.S. Chamber of Commerce countered with $\$ 1.2$ million on behalf of Cochran. ${ }^{245}$ Cochran also made effective overtures to the African American community in advance of the state's open primary. ${ }^{246}$ The successful defense of Cochran was a big victory for the national GOP, and he went on to win reelection without difficulty. ${ }^{247}$

While the GOP was recruiting effective candidates, the independent super PACs, ${ }^{248}$ led by Americans for Prosperity, invested more than $\$ 20$ million in negative advertisements to expose the voting records of vulnerable Senate Democrats. $^{249}$ The focus of the advertisements was the Affordable Care Act, and the key targets were Kay Hagan, Mark Pryor, Mary Landrieu, and Mark Begich. ${ }^{250}$ The 2010 defeat of conservative Democratic senator Blanche Lincoln was certainly related, in no small measure, to her vote for the Affordable Care Act. ${ }^{251}$ To the dismay of the 2014 incumbents, most of the attack advertisements were left unanswered for months, as the big sources of funding for Democratic candidates were held back until closer to the November election. ${ }^{252}$

243. Philip Rucker \& Robert Costa, Republicans Receive Boost in Senate Primaries, Wash. Post (May 20, 2014), https://www.washingtonpost.com/politics/republicans-receive-boost-insenate-primaries/2014/05/20/0f745eb0-e02a-11e3-9743-bb9b59cde7b9_story.html [https://perma.cc/3UEL-T327].

244. Patrick O'Connor, Tea Party's Poll Setbacks Don't Limit Its Washington Clout, WALL ST. J., June 24, 2014, at A4, http://www.wsj.com/articles/tea-partys-poll-setbacks-don't-limit-itswashington-clout-1403743322 [https://perma.cc/C7SQ-HQKS].

245. Id.

246. Janet Hook \& Dante Chinni, Blacks Turned the Tide for Cochran, WALL ST. J., June 26, 2014, at A4.

247. O’Connor, supra note 244; Senate Election Results, N.Y. TimEs (Dec. 17, 2014, 12:28 PM), http://elections.nytimes.com/2014/results/senate [https://perma.cc/S874-P8E7].

248. Super PACs, or Political Action Committees, are committees that work on issues independently of campaigns. See Super PACs, OpenSeCrets.org, https://www.opensecrets. org/pacs/superpacs.php [https://perma.cc/MZ4M-FLMM] (last visited Oct. 30, 2016).

249. Carl Huse, Ads Attacking Health Law Stagger Outspent Democrats, N.Y. TimEs, Jan. 15, 2014, at 1, http:// www.nytimes.com/2014/01/15/us/politics/ads-attacking-on-health-law-staggeroutspent-democrats.html [https://perma.cc/S6UU-AFYK].

250. Id.; see also Emily Schultheis, RNC Radio Ads Target Dems on ACA, Politico (Jan. 7, 2014, 5:41 AM), http://politico.com/story/2014/01/rnc-radio-ads-target-democrats-obamacareaffordable-care-act-101816 [https://perma.cc/DT3J-L9G5].

251. Janet Hook, Democrats Face Battles in South to Hold the Senate, WALl St. J., Dec. 3, 2013, at A1, http://www.wsj.com/articles/democrats-face-battles-in-south-to-hold-the-senate1386041338?tesla=y [https://perma.cc/69UU-59AB].

252. Thomas Catan \& Rebecca Ballhaus, Democrats Take Aim at Early Flurry of GOP Ads, WALLST.J., Feb. 19, 2014, at A4, http://www.wsj.com/articles/SB1000142405270230363640457 
Determining what stance to take on the ACA was a dilemma for Democratic candidates. ${ }^{253}$ In 2012-2013, few Democratic candidates invested money in political advertisements that mentioned the ACA. ${ }^{254}$ In 2014, however, some campaigns shifted from a defensive to an offensive position. ${ }^{255}$ In the spring of 2014, six competitive races for Senate and governor (e.g., North Carolina and Michigan) included pro-ACA television commercials. ${ }^{256}$ These ads focused on the positive aspects of the ACA: coverage for preexisting conditions, preventive care benefits, and the ban on charging women more for health insurance. ${ }^{257}$ The advertisements either supported a pro-ACA member or attacked a member of Congress for opposing the ACA. ${ }^{258}$ For the Democratic Party, the pro-ACA messages were an encouraging change of pace from the barrage of negative ACA messages from the GOP. ${ }^{259}$

\section{The Senate Dilemma for Democrats}

With the GOP strengthening and Democrats at risk, Senate majority leader Harry Reid was in a difficult position in 2013-2014. Harry Reid sought to protect President Obama's first-term accomplishments (e.g., the Affordable Care Act) and move his second-term agenda through the Senate. ${ }^{260}$ Reid also sought to protect his Senate majority by avoiding any roll-call votes by the GOP against vulnerable Democratic senators who were up for reelection in November $2014 .{ }^{261}$

9393523772873960 [https://perma.cc/EC4F-55QB]; Jonathan Martin \& Ashley Parker, Obama Factor Adds to Fears of Democrats, N.Y. TimES, Mar. 15, 2014, at A1, http://nytimes.com/2014/ 03/16/us/politics/obama-factor-adds-to-fears-of-democrats.html [https://perma.cc/2LCY-38EH].

253. Id.; see, e.g., Aaron Blake, Only 36 Percent of Democratic Candidates Have Expressed Supportfor Obamacare, WASH.POST (Sept. 30, 2014), https:/www.washingtonpost.com/news/thefix/wp/2014/09/30/only-36-percent-of-democratic-candidates-have-expressed-support-forobamacare/ [https://perma.cc/5FGM-8Z6E].

254. See Rebekah Metzler, Obamacare Ad Spending to Top $\$ 1$ Billion, U.S. News \& WorLD REP. (July 9, 2013, 3:45 PM), http://www.usnews.com/news/articles/2013/07/09/obamacare-adspending-to-top-1-billion [https://perma.cc/9P32-YR2T].

255. Bianca DiJulio et al., ACA Advertising in 2014-Insurance and Political Ads, HeNRY J. KAISER FAM. FOUND. (Oct. 30, 2014), http://kff.org/report-section/aca-advertising-in-2014-keyfindings/ [https://perma.cc/4MHX-GQB7].

256. Id.

257. Id.

258. Laura Meckler, Some Democrats Talking Up Health Law on Stump, Wall St. J., May 27, 2014, at A4, http://www.wsj.com/articles/some-democrats-talking-up-health-law-on-stump1401242528 [https://perma.cc/V5AF-ZK9M].

259. Id.

260. Richard Rubin \& Billy House, Harry Reid Muscled Obama's Democratic Agenda Through Congress, Bloomberg Pol. (Mar. 27, 2015, 4:32 PM), http://www.bloomberg.com/ politics/articles/2015-03-27/harry-reid-muscled-obama-s-democratic-agenda-through-congress [https://perma.cc/5ZGE-UV8A].

261. Siobhan Hughes, Harry Reid Remains Power Player as Senate Shifts, Wall St. J., Nov. 
During his first term as President, Obama enjoyed a higher degree of roll-call voting support from Democrats in Congress than any President since World War II. ${ }^{262}$ The rate of Democratic defection from Obama's agenda increased from ten percent in 2009 to twenty-three percent in 2012, but with Obama's job-approval rating slipping in 2013-2014, Reid faced the potential of a much higher defection rate if he did not exercise careful control over which measures made it to the floor for a vote. ${ }^{263}$

Starting in 2012-2013, Reid refined the rules for floor consideration so that only a limited number of amendments were permitted for consideration and he could influence which amendments would be considered. ${ }^{264}$ Essentially, Reid retained for himself the right to offer the first set of amendments, which could potentially consume all of the time available for amendments. ${ }^{265}$ In this way, Reid exercised the power to block amendments that he did not want debated on the Senate floor. ${ }^{266}$ Consequently, the number of Republican-sponsored amendments that were considered on the Senate floor declined from 218 in 2007 (Reid's first year as majority leader) to sixty-seven in 2013 (including only four from July to December 2013). ${ }^{267}$

Since Obama possessed a potent veto power, there was not much risk that the Senate and House would be able to enact measures into law against Obama's will. ${ }^{268}$ It is questionable whether blocking the votes on these issues was good for the vulnerable Senate Democrats in 2014, since it likely would have been good for some of those senators to go on record opposing President Obama. ${ }^{269}$ Given how politically "poisonous" Obama was for many Democratic Senate candidates,

12, 2014, at A4, http://www.wsj.com/articles/harry-reid-remains-power-player-as-senate-shifts1415756790 [https://perma.cc/NP2X-MZNV].

262. CQ Roll Call's Vote Studies-2013 In Review, CQ (Feb. 3, 2014), http://media.cq.com/ votestudies/ [https://perma.cc/K3G6-78RG].

263. Peter Baker \& Jeremy W. Peters, As Budget Fight Looms, Obama Sees Defiance in His Own Party, N.Y. Times, Sept. 17, 2013, at A13, http://www.nytimes.com/2013/09/18/us/politics/asbudget-fight-looms-obama-sees-defiance-in-his-own-party.html [https://perma.cc/5GAY-PM34].

264. BAKER, supra note 191, at 39.

265. Id.

266. Charlie Cook, Blocking the Vote, NAT'L J., July 26, 2014, at 15, https://www. nationaljournal.com/s/43437 [https://perma.cc/V5QZ-P4J8].

267. Jonathan Weisman, Reid's Uncompromising Power Play in Senate Rankles Republicans, N.Y.TIMES (Jan. 9, 2014), http://www.nytimes.com/2014/01/10/us/politics/reids-uncompromisingpower-play-in-senate-rankles-republicans.html?mtrref=www.google.com [https://perma.cc/F6B9$5 \mathrm{VWF}]$.

268. $I d$.

269. Kristina Peterson, Midterm Elections 2014: Republicans'Agenda Takes Place, WALL ST. J., Nov. 5, 2014, at A4, http://www.wsj.com/articles/midterm-elections-2014-republicans-agendatakes-shape-1415235922 [https://perma.cc/4E52-N9CG]; Oliphant, supra note 173; Benjy Sarlin \& Alex Seitz-Wald, Why the Democrats Lost, According to Everyone, MSNBC (Nov. 7, 2014, 10:54 AM), http://www.msnbc.com/msnbc/why-the-democrats-lost-midterms-accordingeveryone\#54977 [https://perma.cc/X6AC-88Z8]. 
many of them were looking for opportunities to distance themselves from the President. ${ }^{270}$ Reid decided against creating those opportunities and instead sought to minimize the number of roll-call votes and promote party unity. ${ }^{271}$

Reid blocked votes on a variety of issues where a bipartisan group of senators might have embarrassed the Obama administration. ${ }^{272}$ Reid blocked votes on issues including a binding measure to approve the Keystone pipeline, a measure to delay the EPA's new regulations to limit carbon dioxide pollution, and a measure to expedite approval of export terminals for natural gas. ${ }^{273} \mathrm{~W}$ ith Reid's measures, Senate Democrats went into the November election without much opportunity to separate themselves from the Obama administration.

\section{FUNDRAISING AND CAMPAIGNING IN 2014}

Although Obama was unpopular, he proved again in 2014 that he was an effective fundraiser for the Democrats. ${ }^{274} \mathrm{He}$ led dozens of fundraisers in 20132014, most of them in New York or California. ${ }^{275}$ By August 2014, Obama was on track to surpass all recent presidents in midterm fundraising events except for Bill Clinton's 1998 fundraising efforts. ${ }^{276}$ In 2014, Obama was even more visible at fundraisers, but also remained as invisible as possible in most races where Democratic candidates for Senate were on the ropes. ${ }^{277}$ Obama did not headline any public campaign events in the 2014 election cycle and appeared for only a few candidates where the race was not in question. ${ }^{278}$

The Democratic plan was to use the Obama fundraising not only to support vulnerable candidates but also to mobilize the Democratic base to register and vote. ${ }^{279}$ The Democratic effort to mobilize the base paid off as the polls in 2014

270. Martin \& Parker, supra note 252.

271. Niels Lesniewski, Vulnerable Senate Democrats Almost Always Voted with Obama, RoLL CALL (Oct. 27, 2014, 11:42 AM), http://www.rollcall.com/news/home/senate-votes-2014-cqsenate-democrats-obama [https://perma.cc/G4V3-RMWP].

272. Stephen Dinan \& S.A. Miller, Harry Reid Lords Over Crippled Congress, WASH. Times (July 7, 2014), http://www.washingtontimes.com/news/2014/jul/7/harrys-rules-reid-dominatescrippled-congress/ [https://perma.cc/99FU-RDFQ].

273. Harry Reid's Senate Blockade, WALL ST. J. (May 13, 2014, 7:03 PM), http://www.wsj. com/articles/SB10001424052702304081804579560251530777852 [https://perma.cc/824M-AF99].

274. See, e.g., Paul Steinhauser, Obama 2014 Campaign Role: Fundraiser-in-Chief, CNN (Mar. 20, 2014, 11:45 AM), http://politicalticker.blogs.cnn.com/2014/03/20/obama-2014campaign-role-fundraiser-in-chief/ [https://perma.cc/CZ4P-SR97].

275. Id.

276. Nelson, supra note 57.

277. Carol E. Lee \& Colleen McCain Nelson, On the Trail, Obama's Hard to Find, Wall ST. J., Oct. 10, 2014, at A4, http://www.wsj.com/articles/on-the-campaign-trail-obamas-hard-to-find1412973084 [https://perma.cc/4L8C-LPGN]

278. Id.

279. Frank James, Obama Helps 2014 Democrats One Way He Still Can-With Cash, NPR (Nov. 26, 2013, 6:48 PM), http://www.npr.org/sections/itsallpolitics/2013/11/26/247397816/obama- 
showed that Democratic candidates performed better among all registered voters than among "likely" voters. ${ }^{280}$ Voter turnout was a weakness for the Democrats in midterm elections, and the Senate Democratic Campaign Committee was determined to compensate for this weakness. ${ }^{281}$ Without better outreach to Democratic voters, midterm voters would be disproportionately Republican in orientation (i.e., older, white, male) ${ }^{282}$ Consequently, to enhance Democratic voter turnout, the Democratic Campaign Committee set its budget for outreach efforts at $\$ 60$ million in 2014 , up from $\$ 7$ million in $2010{ }^{283}$

An awkward problem for the national Democratic Party was that House Speaker Nancy Pelosi's fundraising machine for House Democrats was also highly effective, drawing large sums of donations to House races. ${ }^{284}$ Unfortunately, few House seats were in play, and therefore more money for the House races did not do much good for the Democratic Party. ${ }^{285}$ It was control of the Senate that was at stake, and funds donated for the House and Senate are not fungible. ${ }^{286}$

On television, the GOP-sponsored advertisements in Senate races were most likely to mention Obama or the ACA as key issues. ${ }^{287}$ Through these advertisements, the GOP sought to nationalize the election. ${ }^{288}$ The Democraticsponsored advertisements were divided equally between defending the ACA and the recent progress in creating jobs and reducing unemployment. ${ }^{289}$ One point is

helps-2014-democrats-one-way-he-still-can-with-cash [https://perma.cc/8HF8-XJUH].

280. Kohut, supra note 219.

281. Janet Hook, Democrats Stick to Game Plan, Wall ST. J., Mar. 21, 2014, at A4, http://www.wsj.com/articles/SB 10001424052702304026304579451692586375538 [https://perma.cc/2QXM-J7BZ].

282. Gerald F. Seib, 2014 vs. 2012: Two Portraits of American Voters, WaLl St. J., Oct. 27 , 2014, at A4, http://www.wsj.com/articles/2014-vs-2012-two-portraits-of-american-voters-14144 33891 [https://perma.cc/AL6E-NCWG].

283. J.P. Green, Political Strategy Notes, The Democratic Strategist (June 23, 2014, 6:33 AM), http://thedemocraticstrategist.org/2014/06/ [https://perma.cc/XJ4P-KP4V].

284. Lauren French, Pelosi Raises over $\$ 100$ Million, Politico (Nov. 3, 2014, 1:33 PM), http://www.politico.com/story/2014/11/nancy-pelosi-fundraising-2014-112458 [https://perma.cc/4CZL-L8X2].

285. Jessica Taylor, Few House Seats Up for Grabs in 2014, MSNBC (Sept. 12, 2013), http://www.msnbc.com/the-daily-rundown/few-house-seats-grabs-2014 [https://perma.cc/3QXTZQUD].

286. Charlie Cook, Wrong Target, CoOK PoL. ReP. (Feb. 11, 2014), http://cookpolitical. com/story/6743 [https://perma.cc/W6X4-JEDC].

287. $I d$.

288. Dhrumil Mehta \& Harry Enten, The 2014 Senate Elections Were the Most Nationalized in Decades, FiveThiRTyEight (Dec. 2, 2014, 4:04 PM), http://fivethirtyeight.com/datalab/the2014-senate-elections-were-the-most-nationalized-in-decades/ [https://perma.cc/EF9J-F677].

289. Patrick O'Connor, Government Shutdown Fades as Campaign Problem for GOP, WALL ST. J., Sept. 25, 2014, at A4, http://www.wsj.com/articles/government-shutdown-fades-ascampaign-problem-for-gop-1411689416 [https://perma.cc/E9JM-J88M]. 
apparent from the advertisements: Obama and the ACA remained big issues in the 2014 midterm election as they were in $2010 .^{290}$

\section{Dimensions OF THE 2014 MASSACRE}

Come Election Day, the composition of 2014 voters followed a familiar pattern: disproportionally fewer youth and minority voters. ${ }^{291}$ From the battleground states where the fate of the Senate was determined, the Democratic Party did reduce the anticipated decline in turnout among its traditional voter pool. ${ }^{22}$ Following the 2014 election, exit polls revealed that the distribution of voters for Republican House candidates was similar to the 2010 distribution: "in 2014: $60 \%$ white, $25 \%$ Hispanic, $10 \%$ black; $5 \%$ other; in $2010: 60 \%$ white, $28 \%$ Hispanic; $9 \%$ black; $3 \%$ other. ${ }^{293}$ The 2014 election proved to be a dazzling year for the Republican Party.

The Republicans led the House with a 234-201 majority. ${ }^{294}$ In 2014, Republicans increased that majority to $247-188$, the party's largest majority in almost a century. ${ }^{295}$ In the Senate, the Democratic Party held a 55-45 majority. ${ }^{296}$ The Republicans, however, gained nine seats, seizing a 54-46 majority. ${ }^{297}$

The Louisiana race for Senate was not resolved in November due to multiple candidates being on the ballot. ${ }^{298}$ Louisiana held a special runoff election in December to resolve the competition between the two largest vote-getters: Senator Landrieu (seeking a fourth term) and Republican congressman Bill Cassidy. ${ }^{299}$ Incumbent senator Mary Landrieu, while running first in the field, was unable to muster fifty percent of the vote. ${ }^{300}$

290. Id.

291. Ronald Brownstein, Shellacking, the Sequel, Atlantic (Nov. 7, 2014), http://www.theatlantic.com/politics/archive/2014/11/shellacking-the-sequel/438966/ [https://perma.cc/7FRG-6HLV].

292. Nate Cohn, For Democrats, Turnout Efforts Look Successful (Though Not Elections), N.Y.Times (Nov. 14, 2014), http://www.nytimes.com/2014/11/15/upshot/evaluating-the-successof-democratic-get-out-the-vote-efforts.html? mtrref=www.newsdiffs.org\&gwh=797007 1C9CEF5A6649FD219540DD2155\&gwt=pay [https://perma.cc/T9WB-54G3].

293. Brownstein, supra note 291.

294. Domenico Montanaro et al., Breaking Down the 2014 Republican Wave, PBSNEWSHOUR (Nov. 5, 2014, 9:23 AM), www.pbs.org/newshour/updates/breaking-2014-republican-wave/ [https://perma.cc/8Z8D-N8KU].

295. Id.

296. United States Senate, Party Division in the Senate, 1789-Present, Senate.gov, www.senate.gov/history/partydiv.htm [https://perma.cc/2W4P-VKVG] (last visited Oct. 30, 2016).

297. $I d$.

298. Louisiana Election Results, N.Y. TIMES (Dec. 17, 2014, 12:28 PM), http://elections. nytimes.com/2014/louisiana-elections [https://perma.cc/X8UH-BD5M].

299. Id.

300. James Hohman, Dems' Final Insult: Landrieu Crushed, Politico (Dec. 6, 2014, 9:49 PM), http://www.politico.com/story/2014/12/bill-cassidy-mary-landrieu-2014-louisiana-senate- 
Prior to the November election, Senate majority leader Harry Reid blocked a roll-call vote on the Keystone pipeline, ${ }^{301}$ even though such a vote might have allowed Landrieu to create some distance between her image and that of President Obama. White voters in Louisiana were expected to dominate the midterm contest. $^{302}$ Of the Louisiana white voters, seventy-three percent "strongly disapproved" of Obama. ${ }^{303}$ Recognizing that Landrieu was on the ropes, Reid allowed a Keystone vote to be scheduled on the Senate floor before the runoff election in Louisiana. ${ }^{304}$

The House easily passed a measure, authored by Republican congressman Bill Cassidy, approving the Keystone project. ${ }^{305}$ In the Senate, however, Landrieu worked hard to find the sixty votes necessary to overcome a filibuster threat. ${ }^{306}$ Landrieu came up one vote short in finding the necessary votes to overcome a filibuster threat and her constituents voted in the runoff knowing that she was unable to deliver the Keystone pipeline. ${ }^{307}$ She lost the runoff by twelve percentage points, handing the GOP their ninth pick-up in the Senate. ${ }^{308}$

Shortly after taking control of the Senate in January, the GOP made the Keystone pipeline their first item of business, despite a veto threat from President Obama. ${ }^{309}$ After open debate on forty-one amendments, the Senate voted 62-36 to approve the Keystone pipeline. ${ }^{310}$ While this vote was a strong majority, it was

elections-results-113367 [https://perma.cc/9DZT-ALYY].

301. Humberto Sanchez, Keystone Talks Fail; Reid Blocks GOP Energy Amendments, RoLL CALL (May 7, 2014, 2:44 PM), http://www.rollcall.com/news/home/keyston-twist-republicanwants-democrats-to-promise-not-to-filibuster-on-keystone [https://perma.cc/X2JL-74UQ].

302. Melinda Deslatte \& Bill Barrow, Last of Senate's Deep South Democrats Defeated, HufFInGTON POST (Dec. 7, 2014, 11:52 AM), http://www.huffingtonpost.com/huff-wires/ 20141207/us--senate-louisiana/?utm_hp_ref=green\&ir=green [https://perma.cc/6GSN-2MJV].

303. Id.

304. Ginger Gibson, Keystone XL Pipeline Boosted by Louisiana Senate Race, InT'L Bus. Times (Nov. 12, 2014, 4:48 PM), http://www.ibtimes.com/keystone-xl-pipeline-boosted-louisianasenate-race-1722765 [https://perma.cc/28GG-FUQF].

305. Gregory Roberts, House Sends Bill Cassidy-Sponsored Bill Approving Keystone XL Oil Pipeline to Senate, Advocate (Dec. 10, 2014, 5:44 AM), http://www.theadvocate. com/baton_rouge/news/politics/elections/article_f2107e5e-dd1e-521c-9d34-3791df8a5cf3.html [https://perma.cc/CC88-5Y57].

306. Stephen Dinan \& Ben Wolfgang, Senate Democrats Stiff Mary Landrieu on Keystone XL Pipeline; Green Lobby Wins, WASH. TIMES (Nov. 18, 2014), http://www.washingtontimes.com/ news/2014/nov/18/keystone-xl-pipeline-senate-dems-filibuster/ [https://perma.cc/Z6X5-GKQK].

307. Amy Harder \& Siobhan Hughes, Senate Narrowly Defeats Keystone XL Bill, WALL ST. J., Nov. 18, 2014, at A1, http://www.wsj.com/articles/senate-debates-keystone-xl-pipeline1416333606 [https://perma.cc/XU9J-3VB4]).

308. Hohman, supra note 300.

309. Coral Davenport, Senate Approves Keystone XL Pipeline Bill, Testing Obama, N.Y. TiMEs (Jan. 29, 2015), http://www.nytimes.com/2015/01/30/us/politics/keystone-xl-pipeline-billsenate-vote.html [https://perma.cc/4QY7-LQL2].

310. Id. 
still five votes short of the sixty-seven that would be required to override an Obama veto. ${ }^{311}$ Joining a unanimous Republican caucus were nine Democratic crossovers: Michael Bennett, Tom Carper, Bob Casey, Joe Donnelly, Heidi Heitkamp, Joe Manchin, Claire McCaskill, Jon Tester, and Mark Warner. ${ }^{312}$

In summary, once the GOP seized a majority in the Senate in 2014, President Obama was forced for the first time to deal with a Republican majority in both chambers of Congress. The Keystone sage, however, shows that Obama retained significant negative power through the veto.

\section{COnsequences of the Midterm Massacres}

For President Obama, the most damaging aspect of the two midterm elections was the 2010 loss of a Democratic majority in the House of Representatives. From the moment that Republican John Boehner became Speaker of the House, Obama's aspirations for progressive policy change through legislation were doomed.

If the Speaker of the House does not wish to consider the legislative request of the President, the House rules enable the Speaker to block such consideration (barring highly unusual circumstances) through the Rules Committee. ${ }^{313}$ Speaker Boehner incurred little political risk in using his power to block Obama's agenda, especially given the rapid rise of the Tea Party's influence in the Republican Party.

Perhaps the next most important ramification of the midterm massacres was the collateral losses that the Democratic Party experienced in races for governor and state legislature. ${ }^{314}$ Following the 2010 elections, the Democrats lost a net six governorships (eleven losses, five wins) and a total of 725 state legislative seats around the nation. ${ }^{315} \mathrm{~W}$ ith these Democratic losses, the GOP picked up majorities in twenty-three legislative chambers, the largest state-level gains for the Republican Party since $1966 .{ }^{316}$ The GOP made additional progress at the state level in $2014 .{ }^{317}$

311. Lydia Wheeler, Four More Votes Needed to Override Keystone Veto, ND Senator Says, THE HiLl (Jan. 11, 2015, 10:28 AM), http://thehill.com/blogs/ballot-box/229147-senate-needs-fourmore-votes-to-override-a-keystone-xl-veto [https://perma.cc/CR3H-D65L].

312. Paul Singer, Senate Approves Keystone Pipeline Despite Veto Threat, USA TodAY, Jan. 29, 2015, at 3A, http://www.usatoday.com/story/news/politics/2015/01/29/senate-keystone-billobama-veto/22521107/ [https://perma.cc/2EA9-5HKZ].

313. Victor Xing, How Powerful Is the United States Speaker of the House of Representatives?, QuORA (Dec. 6, 2015), https://www.quora.com/How-powerful-is-the-UnitedStates-Speaker-of-the-House-of-Representatives [https://perma.cc/P5VJ-SKQP].

314. See infra notes $316-18$ and accompanying text.

315. Audrey Wall, 2010 Legislative Elections, The Councilof St. Gov'Ts KNowledge CTR. (July 1, 2012, 12:00 AM), http://knowledgecenter.csg.org/kc/content/2010-legislative-elections-0 [https://perma.cc/3TPU-VPGD].

316. Charlie Cook, The Lessons of 2010, NAT'L J., Aug. 2, 2014, at 15.

317. Allysia Finley, Behind the GOP Statehouse Juggernaut, WALL St. J., Dec. 12, 2014, at 
Flowing from the state-level successes in 2010 was a GOP that put itself into a commanding position to control the redistricting process in many states. ${ }^{318}$ Constitutionally, districts are required to be redrawn every ten years, and the GOP influenced the redrawing of many district lines prior to the 2012 election. ${ }^{319}$ The result of this redistricting process was a sharp decline in the number of competitive House seats and an inherent advantage for the GOP until the next redistricting begins after the 2020 elections. ${ }^{320}$ Some analysts believe that the Democratic Party has little prospect of regaining a majority in the House of Representatives before 2022. ${ }^{321}$ Even if a Democrat wins the presidential election in November 2016, it seems likely that a Republican majority in the House will be in place to frustrate the new President's legislative ambitions. ${ }^{322}$

The Democratic loss of the Senate majority in 2014 is of less consequence than it may seem at first blush. For Obama there are few policy reforms that he has been able to enact into law with fifty-five Democrats in the Senate that he cannot enact with forty-six Democratic seats. ${ }^{323}$ This is because sixty votes are typically required in the Senate. ${ }^{324}$ Moreover, because Obama lacks a sympathetic House majority, the switch of the Senate majority is of very limited policy significance. $^{325}$

The loss of the Senate majority in 2014 may also be of less long-term significance than the loss of the House majority in 2010, because the structure of the Senate elections in 2016 created a distinct possibility that the Democrats could retake the Senate majority in January $2017 .{ }^{326}$ The four-seat Senate cushion that the Republic Party won in 2014 diminished the likelihood that the Democrats

A11,http://www.wsj.com/articles/allysia-finley-behind-the-gop-statehouse-juggernaut-1418425930 [https://perma.cc/NGK6-BVDJ].

318. W. Gardner Selby, Republicans Won More House Seats Than More Popular Democrats, Though Not Entirely Because of How Districts Were Drawn, Politi Fact (Nov. 26, 2013, 12:00 PM), http:/www.politifact.com/texas/statements/2013/nov/26/lloyd-doggett/democrats-outpolledrepublicans-who-landed-33-seat/ [https://perma.cc/KV3V-T7J3].

319. Id.

320. 'Gerrymandering on Steroids': How Republicans Stacked the Nation's Statehouses, HeRE \& Now (July 19, 2016), http://www.wbur.org/hereandnow/2016/07/19/gerrymanderingrepublicans-redmap [https://perma.cc/RHE9-9MLP].

321. Susan Davis, Why Democrats Can't Win Back the House, USA TodAY (Aug. 11, 2014, 10:59 AM), http://www.usatoday.com/story/news/politics/2014/08/10/house-republican-majority2014/13585905/ [https://perma.cc/WG28-2DL6].

322. Id.

323. Id.

324. Burt Neuborne, Senate 60-Vote Rule is an Abuse of Democracy, THE HiLl (April 24, 2013, 4:12 PM), http://thehill.com/blogs/congress-blog/politics/295859-senate-60-vote-rule-is-anabuse-of-democracy [https://perma.cc/MT95-XQCU].

325. Id.

326. Josh Katz, Democrats Have a 60 Percent Chance to Retake the Senate, N.Y. Times (Aug. 24, 2016), http://www.nytimes.com/2016/08/24/upshot/democrats-have-a-60-percent-chance-toretake-the-senate.html?_r=0 [https://perma.cc/C7ST-ZTZQ]. 
would be able to win enough seats in the November 2016 elections to recapture the Senate majority, but a Democratic House majority was much less likely than a Democratic Senate majority. ${ }^{327}$

\section{Key Elements of a Counterfactual Obama Presidency}

Without question, the midterm massacres were devastating to President Obama and the Democratic Party. Obama's policy agenda and low job-approval ratings contributed to the massacres. What steps could have been taken by the Obama White House to mitigate the massacres, without simply surrendering the President's policy agenda? The details of a counterfactual Obama presidency are described in a recent book-length examination of the Obama presidency, ${ }^{328}$ but here are the key elements of a strategy that Obama might have taken to advance his agenda while protecting the careers of dozens of moderate Democrats in Congress.

First, the Obama White House should have taken firm steps to detoxify his health care initiative from a political perspective. For starters, the most controversial ideas in the debate should have been taken off the table at the start: the single payer idea and the public option, since neither idea could be passed in the Senate but both were used by the Tea Party and the GOP leadership to paint Obama as a proponent of socialized medicine. The House vote on a bill that included the public option proved to be an unnecessarily controversial vote for House Democrats. ${ }^{329}$ Moreover, Obama's original campaign stance against the individual mandate was politically prudent, and should have been maintained throughout the debate on the Affordable Care Act. The individual mandate was the most unpopular feature of the Affordable Care Act, ${ }^{330}$ and the Obama administration ultimately took numerous executive steps to delay and weaken it. ${ }^{331}$ In other words, House and Senate Democrats voted for a version of the Affordable Care Act that was much more controversial than it needed to be. The other key features of the Affordable Care Act, if implemented properly, would not have hurt the President or his party politically, especially the insurance

327. Larry J. Sabato, Kyle Kondik \& Geoffrey Skelley, Senate 2016: Flip Flop, UnIV. OF VA. CTR. FOR POL. (Sept. 1, 2016), http://www.centerforpolitics.org/crystalball/articles/senate-2016flip-flop/ [https://perma.cc/ETY9-UWP4].

328. See generally John D. Graham, Obama on the Home Front: Domestic Policy TriUMPHS AND SETBACKS (2016).

329. See Dan Lothian, Senate Panel Votes Down Public Option for Health Care Bill, CNN (Sept. 29, 2009), http://www.cnn.com/2009/POLITICS/09/29/senate.public.option/ [https://perma. cc/ZL64-GTT9].

330. Zachary Tracer \& Caroline Chen, The Individual Mandate: Obamacare's Unpopular, Pivotal Point, Bloomberg (Feb. 12, 2016, 7:11 PM), http://www.bloomberg.com/quicktake/ individual-mandate [https://perma.cc/QN37-F7P3].

331. Chris Jacobs, Weakening Obamacare's Individual Mandate - and the Law, WALL ST. J. (Feb 7, 2015, 8:01 AM), http://blogs.wsj.com/washwire/2015/02/07/weakening-obamacaresindividual-mandate-and-the-law [https://perma.cc/KT5T-J55Q]. 
exchange and the Medicaid expansion. On the implementation side, Obama should have been more attentive in making sure he had the proper expertise in place at the Department of Health and Human Services to implement the insurance exchanges and avoid the web site fiasco that hurt Senate Democrats in $2014 .{ }^{332}$

Second, the Obama White House should have pursued climate policy with executive actions, since the U.S. Supreme Court had already ruled that the EPA had the power to address climate change under the Clean Air Act. ${ }^{333}$ The legislative "cap and trade" proposal added unnecessary controversy to Obama's first term, and forced numerous House Democrats to take a bad vote. Since it was fairly clear from the outset that "cap and trade" would be difficult to pass in the Senate (indeed a Senate vote was never taken on Obama's proposal), the White House should never have asked for a vote in the House.

Finally, the President should have included in his 2009-2010 legislative agenda some initiatives that would have been appealing to centrist House Democrats who need to collaborate with some Republicans in order to buttress their credibility among constituents and donors. Promising examples of centrist initiatives that Obama did support later in his presidency are regulatory reform and corporate tax reform. Those long-run, pro-growth initiatives could have been championed by centrists in the Congress as complementary to Obama's near-term economic-recovery efforts.

In sum, Obama was an effective President on his domestic agenda but could have been even more effective over his eight-year reign if he had not contributed to such large Democratic defeats in his two midterm elections. For sure, we have shown that some of those losses were inevitable, since they occurred due to factors that were outside of White House control. But, we have also shown the White House handling of health care, ${ }^{334}$ climate change, ${ }^{335}$ and other issues contributed to the midterm massacres, and the electoral losses associated with those issues could have been mitigated.

332. See supra Part XIII.

333. See generally Massachusetts v. Env't. Prot. Agency, 549 U.S. 497 (2007).

334. See supra notes 330-33 and accompanying text.

335. See supra note 334 and accompanying text. 